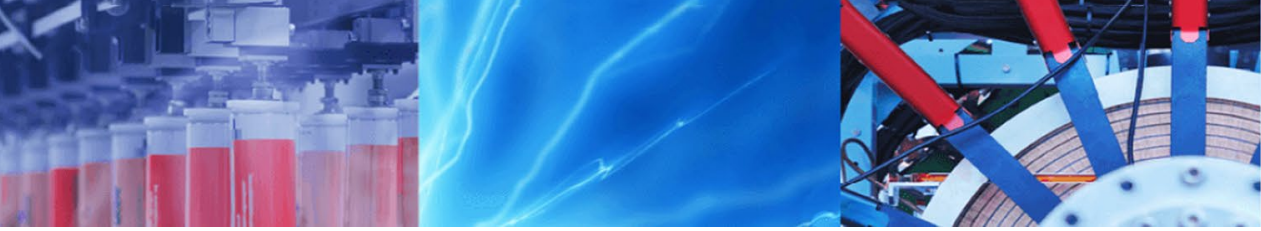

Research Article

\title{
Effects of contamination with gasoline on engineering properties of fine-grained silty soils with an emphasis on the duration of exposure
}

\author{
Abdollah Yazdi ${ }^{1}$ (D) Ebrahim Sharifi Teshnizi ${ }^{2}$ (D) \\ Received: 11 February 2020 / Accepted: 5 May 2021 \\ Published online: 19 June 2021 \\ (c) The Author(s) 2021 OPEN
}

\begin{abstract}
Leaking tanks may lead to severe contamination of their surrounding soil. The geotechnical behavior of the soil varies with the physicochemical processes that occur between the contaminant and the soil. In this respect, studying the geochemical properties of gasoline-contaminated soils and sediments seems to be important for engineering and especially environmental purposes. In this paper, laboratory tests were carried out to examine the effects of crude gasoline contamination on some of the geotechnical properties of a silty soil sampled from the Mashhad plain, located in the northeast of Iran. Tests consisted of basic properties, Atterberg limits, compaction, direct shear, and uniaxial compression tests, which were carried out on clean and contaminated soil samples at the same densities. The contaminated samples were prepared by mixing the soils with crude gasoline in the amounts of $3 \%, 6 \%, 9 \%$, and $12 \%$ of dry weight and curing periods of 0,7 , 15 , and 30 days. Results indicated a decrease in the friction angle and an increase in the cohesion of the soil by increasing gasoline content. Besides, a reduction in the maximum dry density and optimum moisture content was observed in the compaction test. The increase in gasoline percentage up to $6 \%$ also showed a direct effect on increasing the liquid limit and plastic limit of silty soil, which decreased thereafter. Moreover, any increase in gasoline percentage had a reverse effect on the modulus of elasticity of the soil. The increase in gasoline percentage up to $3 \%$ also had a direct impact on the uniaxial compressive strength of the soil, exceeding which it started to decline. Finally, the effects of contamination duration were examined by testing contaminated samples in periods of 7,15 , and 30 days under natural conditions. The results showed a reverse relationship with all geotechnical properties due to aging and a reduction in the gasoline content due to the evaporation of volatile compounds. Also, the numerical analysis of the laboratory results indicated an increase in settling and the percentage of shear strain beneath the foundation with increasing the contamination level, confirming the laboratory results.
\end{abstract}

Keywords Fine-grained silty soil · Gasoline · Contamination · Geotechnical properties

\section{Introduction}

Human life depends highly on energy sources, especially fossil fuels such as oil, gas, and gasoline. Unlike very low environmental consequences of clean energies, hydrocarbons can alter the environment such as soil and rock [1-4]. In recent years, soil contamination by petroleum products has been intensified due to human activities. In this respect, several techniques such as refining to acceptable standards have been considered for dealing

$\triangle$ Abdollah Yazdi, yazdi_mt@yahoo.com; Ebrahim Sharifi Teshnizi, Ebrahim.sharifiteshnizi@mail.um.ac.ir|'Department of Geology, Kahnooj Branch, Islamic Azad University, Kahnooj, Iran. ${ }^{2}$ Department of Geology, Faculty of Sciences, Ferdowsi University of Mashhad, P.O. Box: 91775-1436, Mashhad, Iran. 
with and responding to these issues. For instance, Croney [5] used sandy soil contaminated with petroleum materials for building non-residential buildings and highways. Similarly, Meegoda et al. [6, 7] suggested the use of contaminated petroleum materials for producing hot asphalt, which resulted in much less cost.

A summary of the studies including soil types, conducted tests, contamination agent(s), and their effects on the geotechnical properties of the soils is presented in Table 1. As the table represents, depending on the soil types, contamination with oil and petroleum by-products has generally a reverse effect on friction angle and shear strength parameters.

Concerns about soil contamination by petroleum products are usually related to leakage or seepage from storage tanks or distribution facilities. However, there are also accidental escapes from refineries due to unfortunate incidents or negligence, where significant amounts of hydrocarbons are released over long periods. Excavation in oilcontaminated areas is one of the most common treatment methods, but it will only move the problem from point to point [1, 37-39].

Petroleum-contaminated soil is one of the most problematic materials in construction projects. The reaction between petroleum contamination and soil causes changes in geotechnical properties. These changes depend on the time of exposure to the contamination such that the longer the contamination of petroleum materials, the more decrease occur in geotechnical properties. Therefore, it leads to a great impact on the design and implementation of construction projects. As can be seen, identifying the behavior and performance of these soils before the design and implementation of any projects is of great importance. Leaking from tanks will contaminate the soil around it. Geotechnical behavior of the soil changes due to the physicochemical processes that occur between the contaminant and the soil. This can change soil behavior and reduce its bearing capacity. Therefore, the stability of the structures will be compromised and soil and groundwater will be polluted, due to damage to tanks and leakage of large amounts of contaminants [2, 38-41].

Most of the previous studies have focused on clayey and sandy soils contaminated with crude oil and no studies have considered the effects of duration of contamination. To the best of our knowledge, the geotechnical behavior of silty soil due to oil contamination has been investigated only by Rahman et al. [17] and Nasehi et al. [29]. Therefore, it is necessary to conduct further studies on other soil types like silty soil and other contaminating agents (such as other by-products of oil like gasoline), as well as considering the contamination exposure duration.

Two main reasons for selecting ML soil type in this study are the following. First, ML is one of the most common soil types in the study area (southern Mashhad, Iran), where most of Mashhad's refineries are built upon and the risk of soil contamination from oil is high. Second, since the previous studies were conducted on different soil types with various chemical components, no unanimous conclusion could be achieved for the contamination effects. Therefore, limiting the soil type to only one type (i.e., ML) may provide valuable insights into the role of fine-grained soil in the interaction of the soil with the contaminant. In this way, it can serve as a benchmark for future studies. The laboratory tests carried out in this study consisted of Atterberg limits, direct shear, unconfined compression tests, and compaction characteristics.

\section{Materials and methods}

The experiment procedure followed in this study includes (a) describing the study area where the soil sample and contaminants were obtained and (b) performing the laboratory tests on natural soil and gasoline-contaminated soil.

\subsection{Study area}

The soil used in this study was collected from the south of Mashhad, where residential buildings are being constructed. Due to the topographic conditions of this area, most of the observed sediments are of silty type (Fig. 1). As mentioned before, in this region, some oil refinery and petrochemical industries related to gasoline storage are under construction. Thus, studying the effects of gasoline contamination on the geotechnical properties of this soil type becomes very crucial. Hence, in case of further expansion of these constructions and the occurrence of oil pollution, geotechnical engineers could consider the results of this study before the project and will be able to provide a suitable solution to face this problem and prevent disasters.

Several holes were drilled to a depth of $1 \mathrm{~m}$ in the area to sample from the study area. Figure 2 presents different stages of sampling and drilling for each hole. In situ density testing was performed at the bottom of each hole according to ASTM D1556 standard [42].

\subsection{Materials}

\subsubsection{Soil}

The soil sample used in this study was prepared from the south of Mashhad in a remolded and undisturbed state. This soil is classified as loam according to the classification of the United States Department of Agriculture (USDA). Sieve analysis was conducted on the soil samples 


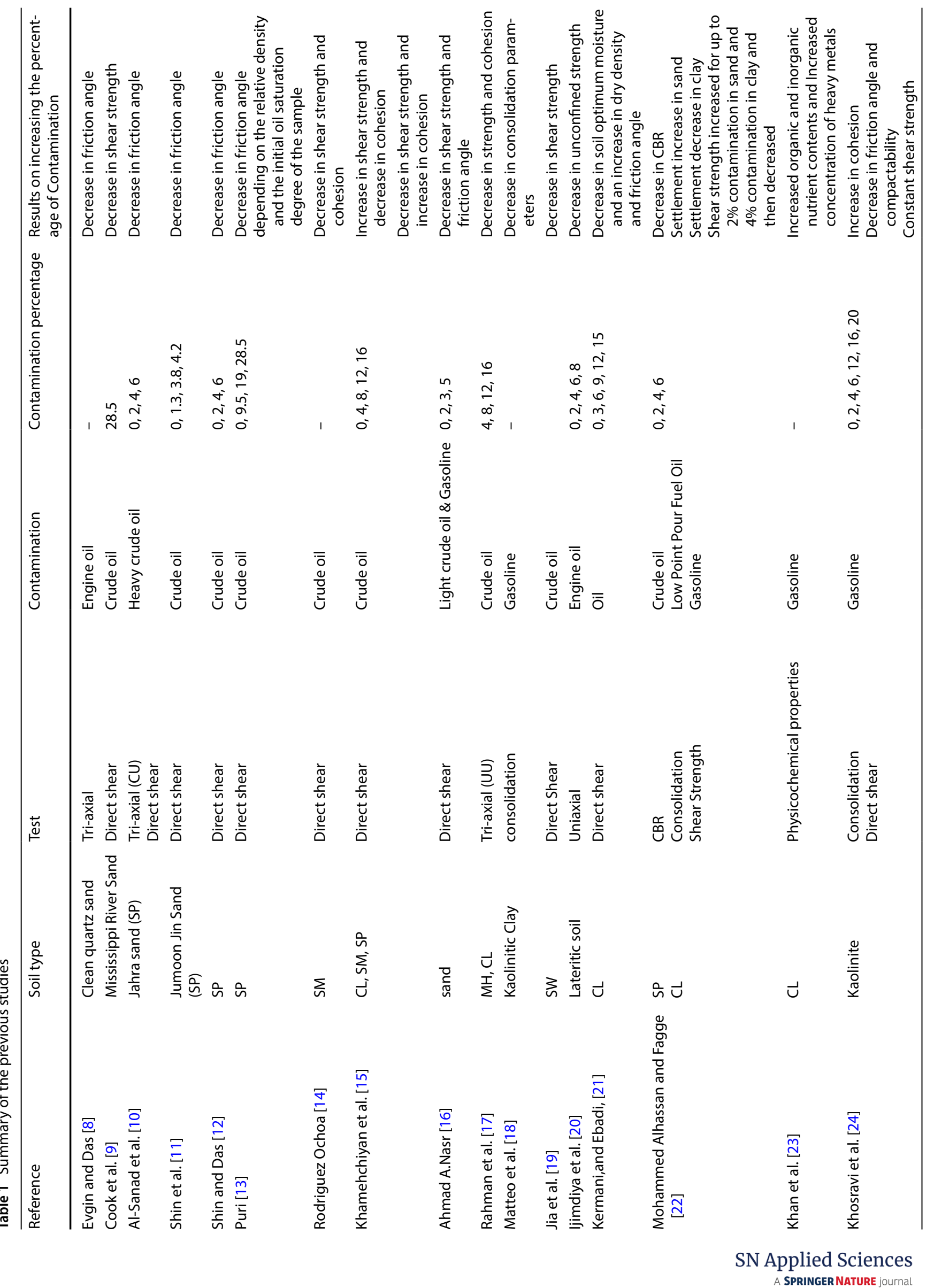




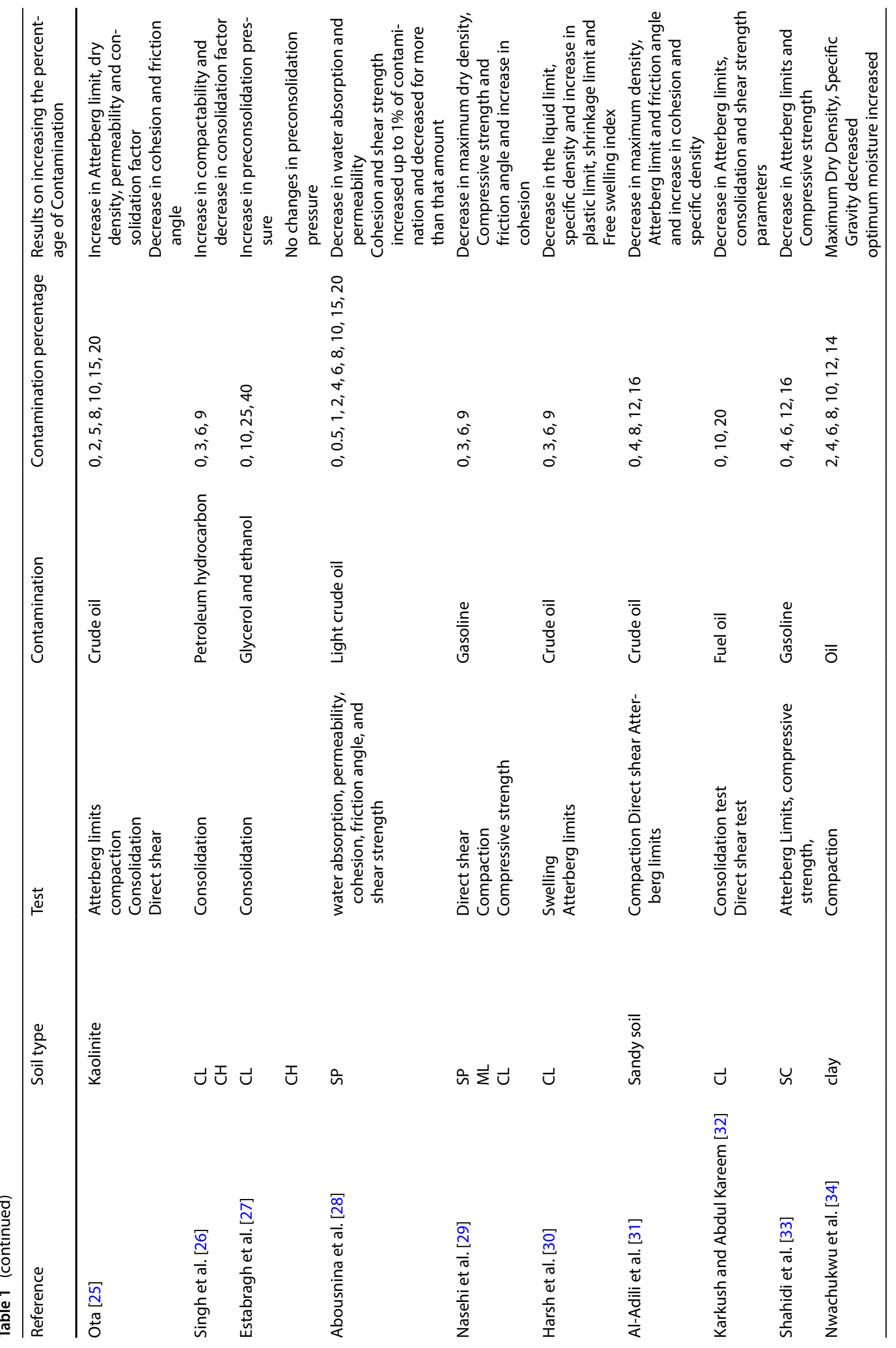


according to the standards of ASTMD422-63 [43], D431817 [44], D 2487 [45], and D854-14 [46]. Figure 3 presents the grain size distribution of all the selected samples. It is classified as ML (lean silt) according to the Unified Soil Classification System (USCS).

Tables 2 and 3 show the results of $X$-ray fluorescence (XRF) and X-ray diffraction (XRD) analysis (Fig. 4) used to determine the chemical composition and mineralogy of soil, respectively. Table 4 presents a summary of the basic properties of the soil type. According to the soil gradation curve, $10 \%$ of the studied soil is clay, $43 \%$ is silt, and $47 \%$ is sand grains.

\subsubsection{Gasoline}

Table 5 represents the properties of the gasoline according to the samples used in the country.

\subsubsection{Water}

In this study, distilled water was used for all experiments.

\subsection{Standards}

The experiments carried out in this study were according to ASTM standards. Table 6 shows the types of tests performed with the corresponding standards.

\subsection{Samples preparation}

After particle size classification, samples were oven-dried at $105^{\circ} \mathrm{C}$ in a $24-\mathrm{h}$ period. Then, the gasoline was sprayed on the samples and mixed manually in the percentages of $0,3,6,9$, and $12 \%$ of the dry weight of the soil samples according to Nasehi et al. [29, 52] and Khosravi et al. [24]. In the next step, the mixture was put into closed containers at room temperature for 7,15 , and 30 days to reach equilibrium. This period is consistent with the 3-7-day period proposed by Singh et al. [26] for soil-contaminant mixtures. Table 7 shows the labeled samples prepared for this purpose.

It is of note that Khamehchiyan et al. [15] and showed that the addition of more than $12 \%$ of oil contamination to the soil is not suitable for sampling in sandy and silty soils. The explanation is that without increasing water, the sample will be on the wet side of the compaction curve and the excess crude oil during compaction tests will drain out of the samples. Therefore, in this study, the gasoline percentages were limited to $0,3,6,9$, and $12 \%$.

The gasoline evaporation from the samples was examined by measuring the daily change in the weight of samples kept at room temperature of $25^{\circ} \mathrm{C}$ such as Zheng et al. [53]. Results showed that the evaporation 
Fig. 1 Location of sampling station in the study area

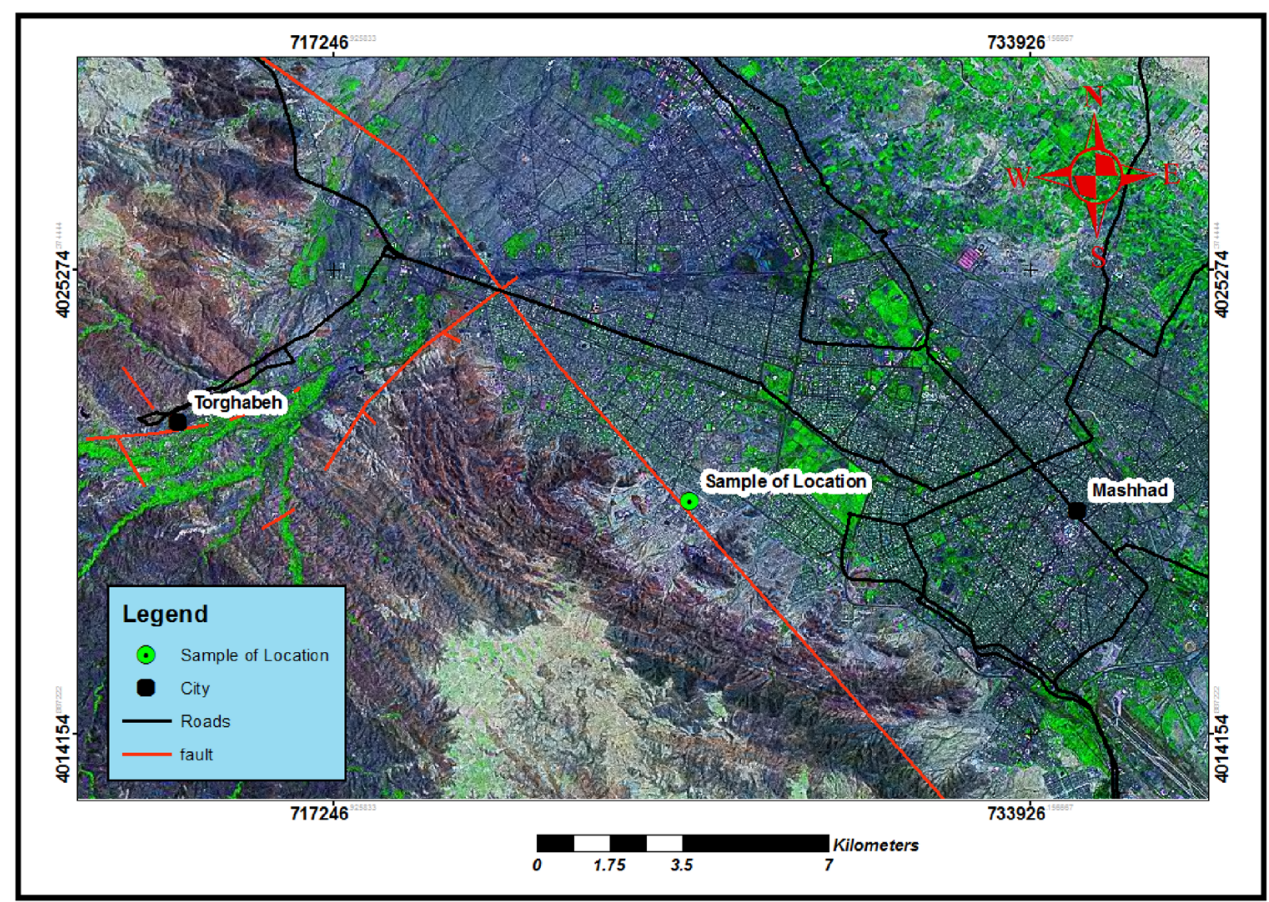

took place at a fairly high rate during the first week, but it continuously decreased with time until it ceased completely after almost four weeks. It was also observed that the total gasoline evaporated from the samples was less than $3 \%$ of the gasoline content used to contaminate the soil. Therefore, the change in the gasoline content due to evaporation was considered insignificant. Figure 5 shows the gasoline evaporation percentage and rate of $M L$ samples in the laboratory environment. ML-3, ML-6, ML-9, and ML-12 samples were kept in different containers and were weighed on consecutive days.

In the study area, a rectangular area $(200 \mathrm{~m} \times 200 \mathrm{~m})$ with 16 holes (with a depth of $1 \mathrm{~m}$ ) was drilled and sampling was done at this depth. Since diesel or any petroleum products have not been contaminated in this area yet, so the samples taken from the soil of the area are free of petroleum contamination. To determine the density of the study area, a sand cone in situ density test was performed according to ASTM D1556 at the bottom of each hole. Considering that there was a difference between the minimum density (approximately $1.64 \mathrm{~g} / \mathrm{cm}^{3}$ ) and the maximum density (approximately $1.7 \mathrm{~g} / \mathrm{cm}^{3}$ ), the relative density was calculated to $95 \%$ $(=1.64 / 1.7)$. The soil density obtained for non-contaminated samples and gasoline-contaminated samples was approximately equal to $1.67 \mathrm{~g} / \mathrm{cm}^{3}$ and $95 \%$ of the laboratory density, respectively (Fig. 2) [1,53]. After the experiments, statistical analysis was performed and the mean data were plotted. It is noteworthy that in all diagrams, $0 \%$ of gasoline is related to the base soil without pollution. All diagrams were compared and analyzed according to the base soil data.

\section{Laboratory testing}

The analysis, design, and construction of most geotechnical projects were done based on test results according to ASTM and AASHTO standards. These standards were followed in laboratory conditions at controlled temperature with distilled water as the pore water. However, these conditions and especially water quality vary in different environments due to infiltration and mixing of various contaminants. Since conditions in the project site and standard conditions are considerably different, premature or progressive failures are very common [54].

Tests conducted in this study to analyze the effects of gasoline contamination on geotechnical properties of the samples included Atterberg limit, compaction, direct shear, and uniaxial compression tests. For the unconfined compression test (UCT) and shear box test, the standard Proctor compaction test was conducted. In this way, the density and optimum moisture content of the samples for different percentages of contamination were obtained. Then, the samples were remolded in the test mold with static compaction at determined maximum dry density 


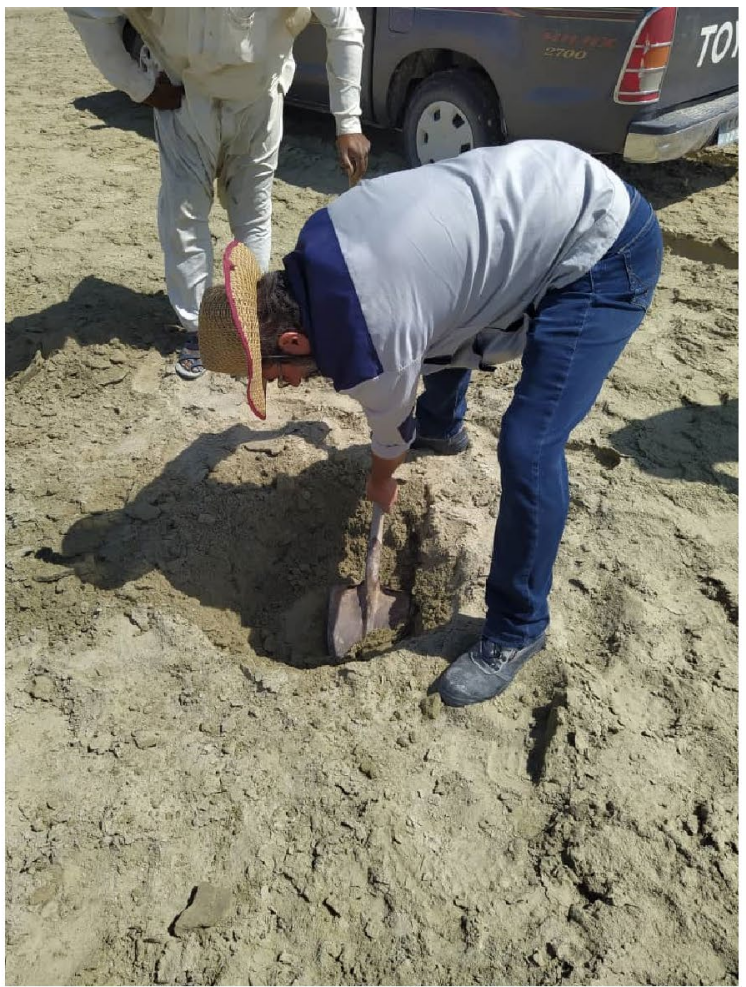

a

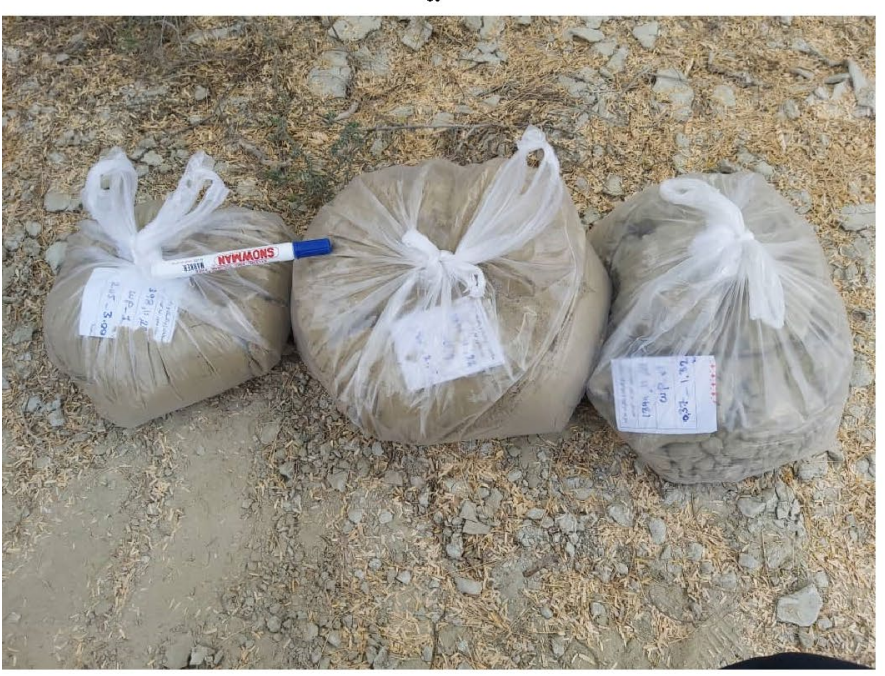

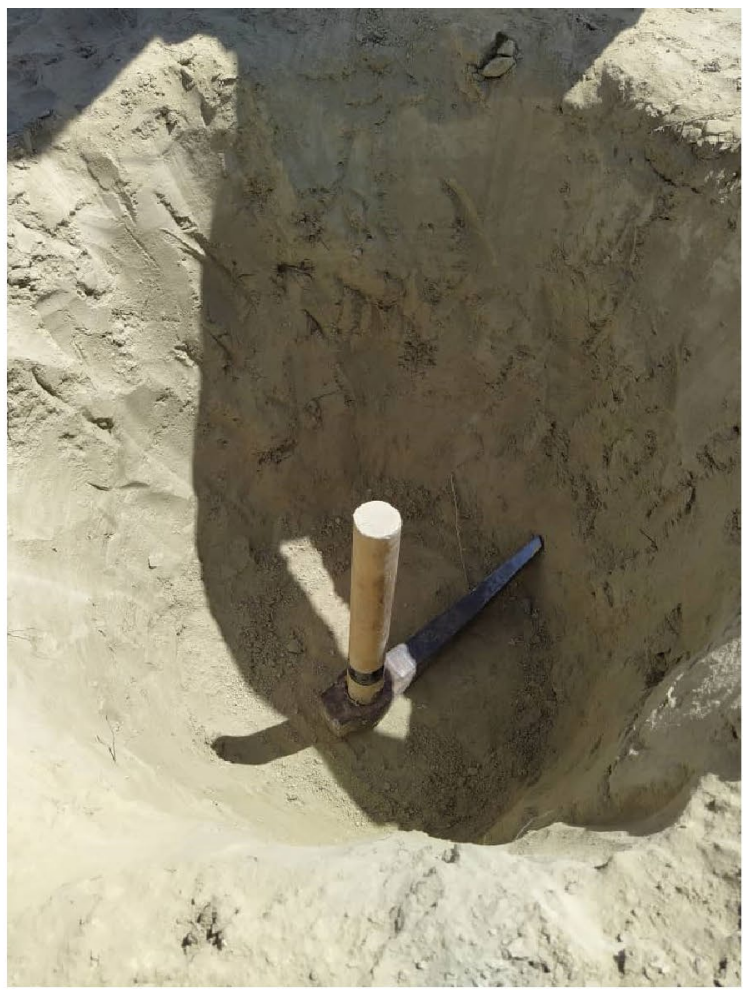

b

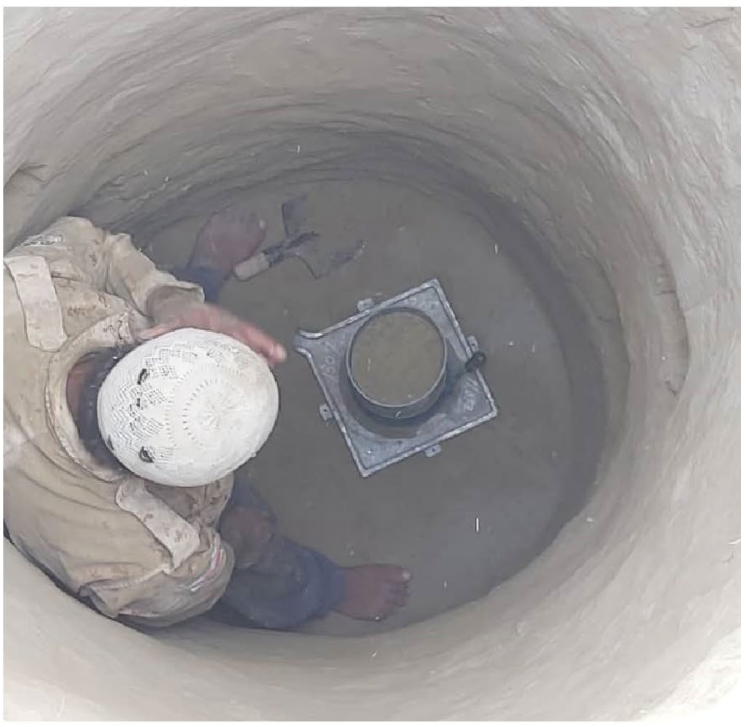

d

Fig. 2 a and $\mathbf{b}$ Different stages of drilling the hole, $\mathbf{c}$ sampling method, and $\mathbf{d}$ determination of in situ density

and optimum moisture content. The tests were carried out according to ASTM D2166 [48] and ASTM D3080 [51] for UCT and shear box tests, respectively. Figure 6 presents the flowchart of the laboratory-testing procedure.
A water pycnometer was used to determine the specific gravity $\left(G_{s}\right)$ following ASTM D854 [46]. The plastic limit and liquid limit were determined based on ASTM D4318 [44]. To determine the maximum dry density, the modified 


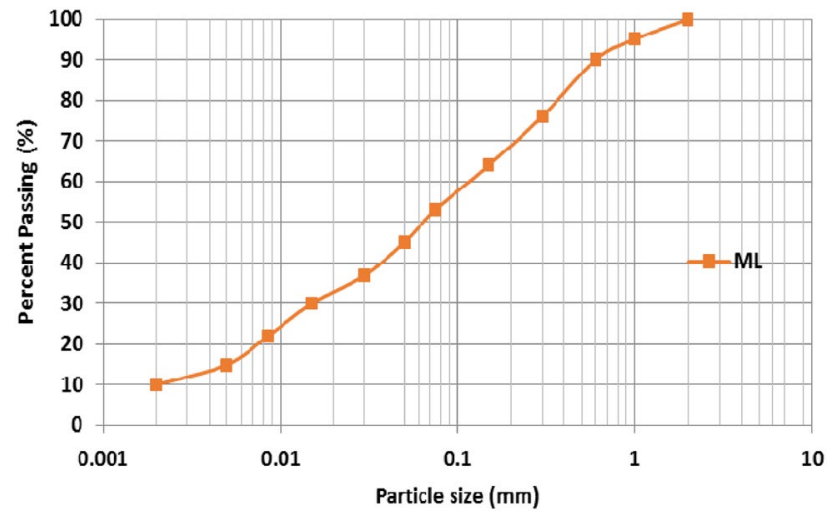

Fig. 3 Gradation curve of the studied soil

Proctor compaction test was carried out on the soil samples based on ASTM D698 [50].

\section{Results and discussion}

\subsection{Atterberg limit}

Atterberg limits or consistency limits are characterized by plastic and liquid limits and plasticity index. The liquid limit represents the minimum water content at which soil particles flow under their weight. On the other hand, the plastic limit is the minimum water content at which soil is molded without breaking. These limits control the consistency of the soils by chanting the wetting conditions. Atterberg limits have very extensive use in geotechnical engineering for the identification, description, and classification of soils. Also, they are considered a basis for the preliminary assessment of their mechanical properties. Furthermore, these limits
Table 3 Mineralogy of soil (XRD result)

\begin{tabular}{ll}
\hline Soil type & Minerals \\
\hline ML & $\begin{array}{l}\text { Quartz, Calcite, Albite, Illite, Gypsum, muscovite, } \\
\text { kaolinite }\end{array}$ \\
\hline
\end{tabular}

are easily determined and their qualitative correlations with soil composition and physical properties have been quite well established. Nevertheless, the fundamental interpretations of the limits and quantitative relationships between their values and compositional factors are more complex $[55,56]$.

Among different gasoline percentages added to the soil, it was found that adding $6 \%$ of diesel oil has increased the liquid limit, exceeding which it started to decline. Also, increased curing time has reduced the liquid limit of the soil. Figure 7 provides an overview of the state of changes in the liquid limit relative to the gasoline content and curing duration.

The addition of gasoline up to $6 \%$ increased the plastic limit, exceeding which it started to decrease. Increasing the curing time has also increased the plastic limit in the soil. Figure 8 shows an overview of the plastic limit change status relative to the percentage of gasoline and curing time.

The addition of gasoline up to $6 \%$ increased the plasticity index and decreased it thereafter. Also, increasing the curing time reduced the plasticity index in the soil. Figure 9 illustrates the status of plasticity index changes related to the gasoline percentage and curing time.

Tables 8 and 9 indicate the statistical analysis of the liquid limit and the plasticity limit results for different samples prepared with different contamination percentages at different times.

The increase in the $\mathrm{LL}, \mathrm{PL}$, and $\mathrm{PI}$ can be described by the theory of the diffuse double-layer. Water is a polar
Table 2 Chemical composition of the soil (XRF results)

Fig. 4 XRD pattern graph of ML sample

\begin{tabular}{lcccccccccccc}
\hline & $\mathrm{SiO}_{2}$ & $\mathrm{Al}_{2} \mathrm{O}_{3}$ & $\mathrm{Na}_{2} \mathrm{O}$ & $\mathrm{MgO}$ & $\mathrm{K}_{2} \mathrm{O}$ & $\mathrm{TiO}_{2}$ & $\mathrm{MnO}$ & $\mathrm{CaO}$ & $\mathrm{P}_{2} \mathrm{O}_{5}$ & $\mathrm{Fe}_{2} \mathrm{O}_{3}$ & $\mathrm{SO}_{3}$ & $\mathrm{LOI}$ \\
\hline Soil & 36.7 & 8.16 & 0.57 & 3.56 & 1.53 & 0.42 & 0.06 & 16.67 & 0.1 & 3.39 & 11.93 & 16.63 \\
\hline
\end{tabular}

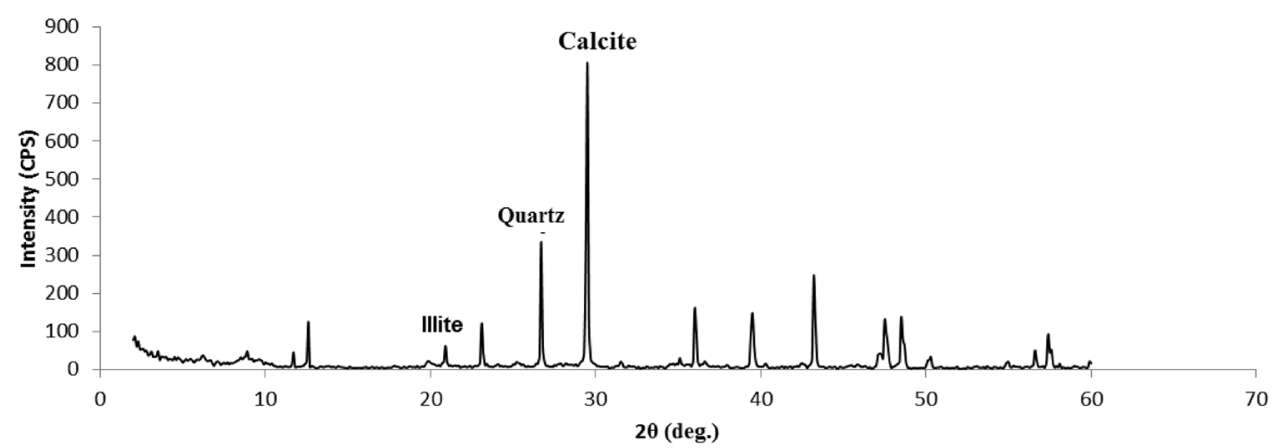


Table 4 Physical and mechanical properties of the soil

\begin{tabular}{ll}
\hline Properties & Soil \\
\hline Gravel (\%) & 0 \\
Sand (\%) & 47 \\
Silt (\%) & 43 \\
Clay (\%) & 10 \\
LL (\%) & 35 \\
PL (\%) & 25.5 \\
PI (\%) & 9.5 \\
GS & 2.7 \\
Unified Classified & ML \\
AASHTO Classified & A-4 \\
Gl & 0 \\
Activity (\%) & 0.95 \\
\hline
\end{tabular}

Table 5 Properties of the gasoline used in this study

\begin{tabular}{lllll}
\hline $\begin{array}{l}\text { Dynamic } \\
\text { viscosity at } \\
20{ }^{\circ} \mathrm{C}\end{array}$ & $\begin{array}{l}\text { Boiling } \\
\text { point }\end{array}$ & $\begin{array}{l}\text { Self-igniting } \\
\text { tempera- } \\
\text { ture }\end{array}$ & $\begin{array}{l}\text { Combus- } \\
\text { tion tem- } \\
\text { perature }\end{array}$ & $\begin{array}{l}\text { Density at } \\
25 \text { degrees } \\
\text { CP }\end{array}$ \\
\hline${ }^{\circ} \mathrm{C}$ & ${ }^{\circ} \mathrm{C}$ & ${ }^{\circ} \mathrm{C}$ & $\mathrm{gr} / \mathrm{cm}^{3}$ \\
\hline $1.7-2$ & $150-390$ & 257 & 56 & $0.8-0.84$ \\
\hline
\end{tabular}

Table 6 Tests performed on the samples and their relevant standards

\begin{tabular}{|c|c|}
\hline Standard & Test \\
\hline ASTM D2166 [47] & Unconfined compression test (UCT) \\
\hline $\begin{array}{l}\text { ASTM D422-63(89) and ASTM } \\
\text { D421-87[43] }\end{array}$ & Grading test and hydrometer \\
\hline ASTM D2216-19 [48] & Determine the moisture content \\
\hline ASTM D854 [46] & Density determination of soil grains \\
\hline ASTM D4452 [49] & Mineralogical experiment (XRD) \\
\hline ASTM D 2487 [45] & Unified soil classification system \\
\hline ASTM D698-12 [50] & $\begin{array}{l}\text { Standard density (Compaction } \\
\text { standard test) }\end{array}$ \\
\hline ASTM D3080 [51] & Direct shear test \\
\hline
\end{tabular}

molecule because the electrons of the hydrogen atoms are "pulled" toward the electrons of the oxygen atom. This makes a zone of positive charge on the hydrogen atoms and the negative charge on the other end of the molecule (i.e., the oxygen atom), which is known as dipole water. Dipole water is attracted both by the negatively charged surface of the clay particles and by the cations in the double layer.

The other mechanism by which water is attracted to clay particles is hydrogen bonding, where hydrogen atoms in the water molecules are shared with oxygen atoms on
Table 7 Labels of clean and contaminated sample

\begin{tabular}{llll}
\hline Mixture name & & Mixes & $\begin{array}{l}\text { Curing } \\
\text { time } \\
\text { (days) }\end{array}$ \\
\hline $\begin{array}{l}\text { Soil } \\
\text { Soil contami- } \\
\text { nated }\end{array}$ & ML0 (control) & natural soil & - \\
& ML3-2 & $3 \%$ Gasoline & 7 \\
& ML3-3 & $3 \%$ Gasoline & 15 \\
& ML6-1 & $3 \%$ Gasoline & 28 \\
& ML6-2 & $6 \%$ Gasoline & 7 \\
& ML6-3 & $6 \%$ Gasoline & 15 \\
& ML9-1 & $6 \%$ Gasoline & 28 \\
& ML9-2 & $9 \%$ Gasoline & 7 \\
& ML9-3 & $9 \%$ Gasoline & 15 \\
& ML12-1 & $9 \%$ Gasoline & 28 \\
& ML12-2 & $12 \%$ Gasoline & 7 \\
ML12-3 & $12 \%$ Gasoline & 15 \\
& $12 \%$ Gasoline & 28 \\
\hline
\end{tabular}

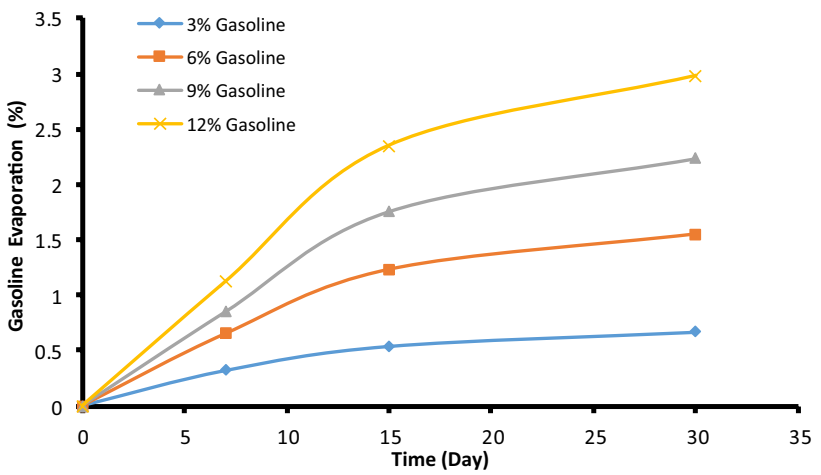

Fig. 5 Gasoline evaporation percentage and rate of samples in the laboratory environment

the surface of the clay. The water held to clay particles by force of the attraction is known as double-layer water. The innermost layer of the double-layer water, which is held very strongly by the clay, is known as adsorbed water. This orientation of water around the clay particles gives finegrained soils their plastic properties. The water in the pore space that is not absorbed by the clay particles and moves easily in the soils is called free water, which determines the liquid behavior of the soil $[56,57]$. Unlike the water molecule, the gasoline molecule is not a dipole. Therefore, while mixing with soil, gasoline molecules cover the soil particles and do not allow water molecules to develop the diffuse double-layer. As a result, more water is needed for the soil to obtain plastic properties. This might be the reason for the increase in the plastic limit. However, if the oil orients the soil particles, most of the water added to the 
Fig. 6 Flowchart of the laboratory-testing procedure

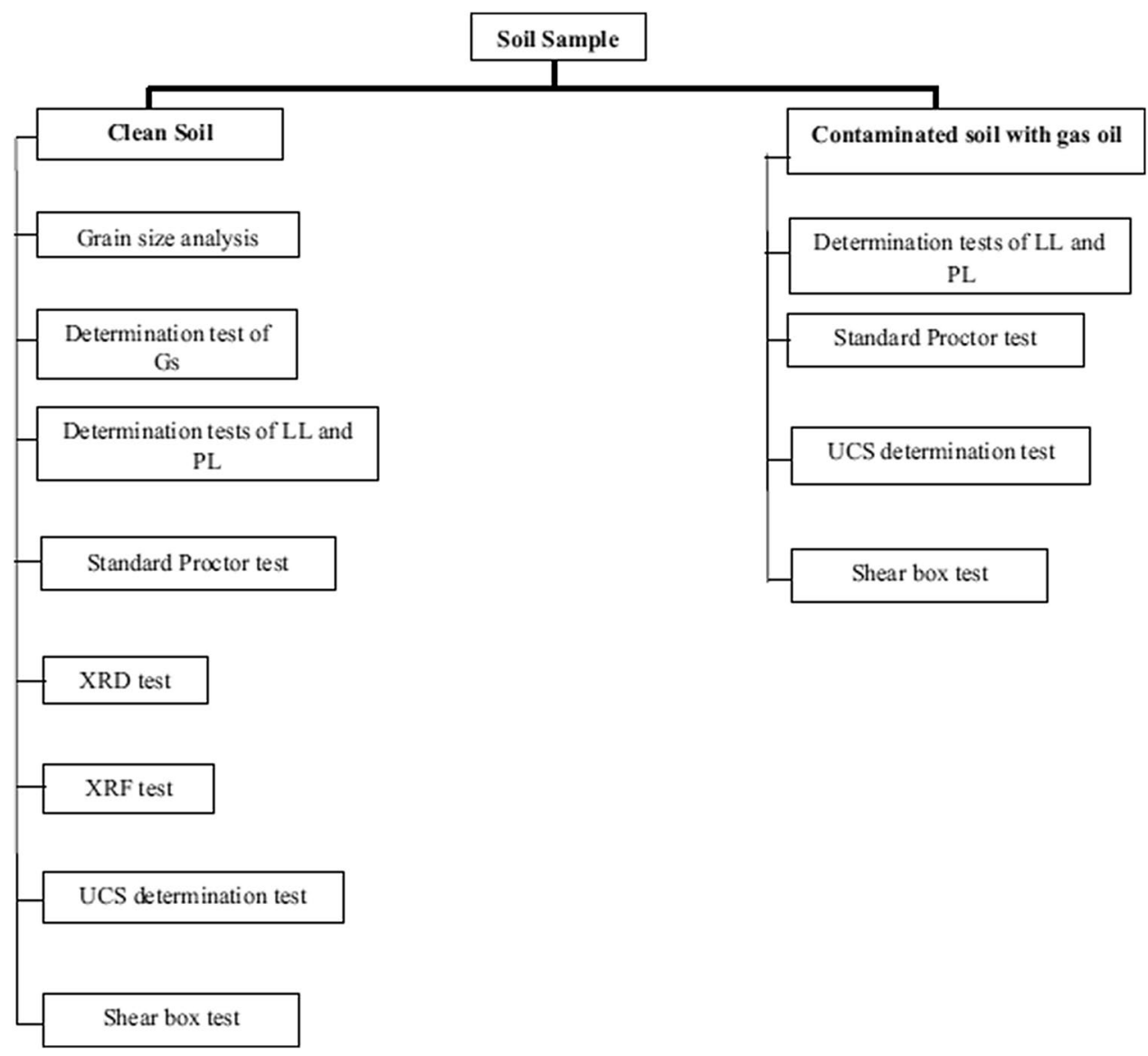

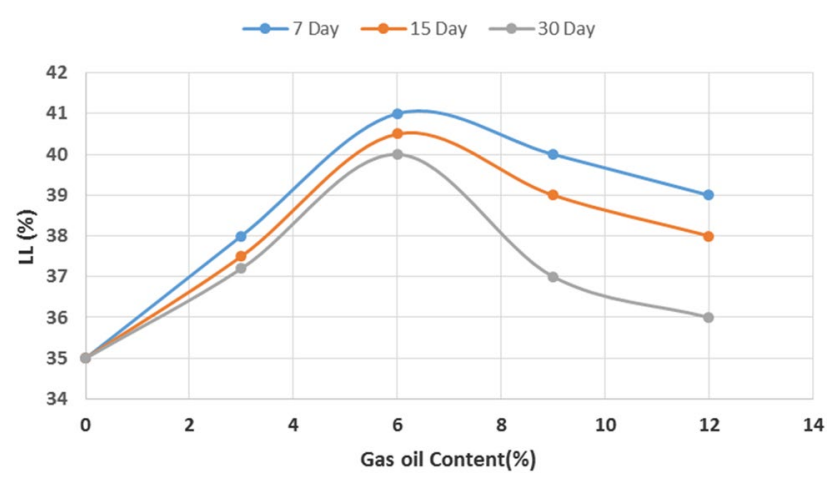

Fig. 7 Liquid limit variation in different curing times and different gasoline contents in fine-grained soil

soil during the test will join the free water. Accordingly, the liquid limit shows a slight increase with increasing the gasoline content [21, 29].

Besides, due to the increase in the cohesion of the ML samples after contamination with gasoline and the development of flocculation fabric in the soils, more water is needed to flow the soil by its weight. This means that shear strength is zero

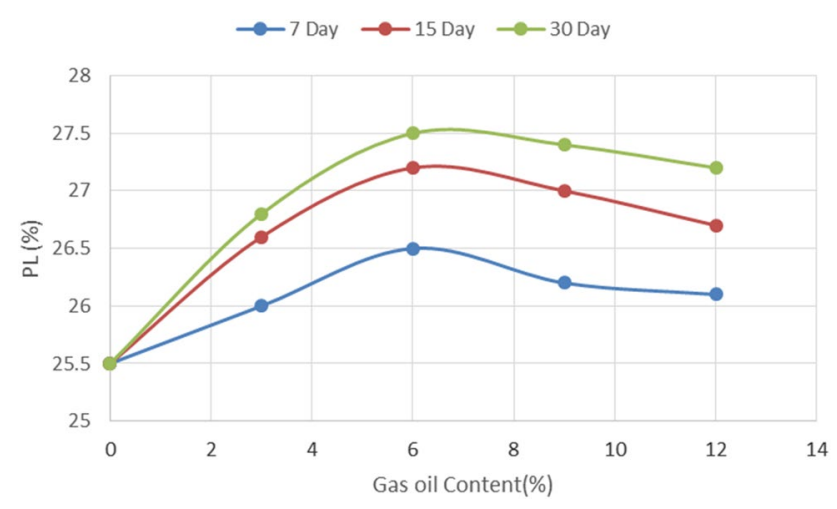

Fig. 8 Plasticity limit variation in different curing times and different gasoline contents in fine-grained soil

and thus the liquid limit starts to increase. By increasing the liquid limit and plastic limit, the plasticity index (PI) of the soil samples decreases. This mechanism, which has been proven by Mitchell and Soga [58], Rehman and Abduljauwad [59], Evgin and Das [8], Nasehi et al. [52] and Sharifi Teshnizi et al. [38], is shown schematically in Fig. 10. 


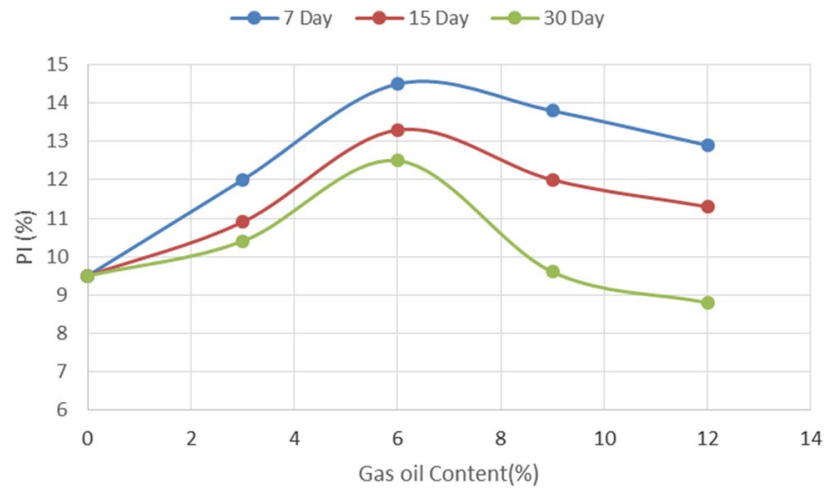

Fig. 9 Plasticity index variation in different curing times and different percentages of gasoline in fine-grained soil

\subsection{Compaction tests}

Standard Proctor compaction tests (ASTM-D698, Method A [50]) were carried out on the soil samples contaminated by gasoline in the laboratory. Figures 11, 12, 13 represent the test results in dry density versus water content diagram at different curing times.

As a general trend, with increasing the gasoline content, the compaction curves for contaminated soils move to the left side of the uncontaminated soil curve. Figure 14 shows the effects of contamination on the maximum dry density at different ages. The variation of the density in the soil samples shows a significant drop when $3 \%$ of gasoline is added to the soil while for the heavily contaminated samples, the density remains almost constant. The decrease in dry density in sandy soil is small since the void spaces are larger and gasoline can move through the soil grains at the same rate as water, indicating a similar lubricating effect. The results are in agreement with those reported by Shah et al. [60], Khamechiyan et al. [15], and Nasehi et al. $[29,52]$. However, they are contrary to those of Al-sanad et al. [61, 62], Meegoda et al. [7], Kermani and Tahgi Ebadi [21], and Solly et al. [63].

Figure 15 shows the relationship between moisture and gasoline contents at different ages. The figure presents a drawdown trend of optimum moisture content with increasing the gasoline content in the samples. This suggests that the water content required to achieve maximum density has decreased with increasing the gasoline content. It is probably related to the lubricating effect of gasoline, which makes the soil a looser material compared to the uncontaminated soils [17]. It is noteworthy that the optimum moisture content of uncontaminated silty soil is relatively higher probably due to the presence of Illite and kaolinite (Fig. 4; Table 3) in the soil and their water absorption characteristics.

\subsection{Unconfined compression tests}

Unconfined compression tests (UCT) were performed on the clean and contaminated ML soil samples according to ASTM D2166 [47] at different ages. An axial strain rate of $1 \% /$ min was applied to the sample until the load values decreased with increasing the strain, or until reaching a strain level of $15 \%$. Figures 16 and 17 show the changes in the UCT and modulus of elasticity with different contents of gasoline at different ages.

The initial increase in UCT of the sample with $3 \%$ gasoline could be attributed to the formation of flocculation fabric because of the contamination (Fig. 10). Generally, flocculated soil has lower compressibility, higher strength, and permeability compared to the same soil in a dispersed state with the same void ratio [64]. Moreover, for contamination up to $3 \%$, a thin layer of gasoline on clay particles serves as a viscous interface and helps the clay retain its structure, thereby increasing the shear strength. For the heavily contaminated samples (i.e., gasoline content greater than $3 \%$ ), the thickness of this layer exceeds a critical value and makes the particles slip over each other. Consequently, the shear strength of the soil decreases.

The results of UCT tests show that increasing the percentage of gasoline and the curing time decreases the modulus of elasticity and increases the plasticity of the samples. Similarly, increasing the operating time reduces the UCT and modulus of elasticity, while an increase in the gasoline content decreases the UCS and modulus of elasticity.

Tables 10 and 11 show the statistical analysis of the results of UCT and modulus of elasticity for different samples prepared with different percentages of contamination at different times.

\subsection{Direct shear tests}

Direct shear tests were carried out on clean and contaminated samples according to ASTM D3080 [51]. The tests were performed in a square shear box $(10 \mathrm{~cm} \times 10 \mathrm{~cm})$ with a rate of shear deformation equal to $0.5 \mathrm{~mm} / \mathrm{min}$ at normal loads of 20,40 , and $60 \mathrm{~kg}$. Tests were carried out in dry conditions to prevent oil drainage from the samples.

Figures 18 and 19 show the changes in the Cohesion and Friction angle in different gasoline contents at different ages. Results represent a general trend of increase in cohesion and decrease in friction angle of contaminated samples by increasing the contamination content. In this soil type, a small decrease in cohesion is observed in $3 \%$ of contamination at the age of 30 days. The results are in agreement with those reported by Khosravi et al. [24], but inconsistent with those found by Shah et al. [60] and Kermani and Ebadi [21]. The increase in cohesion 


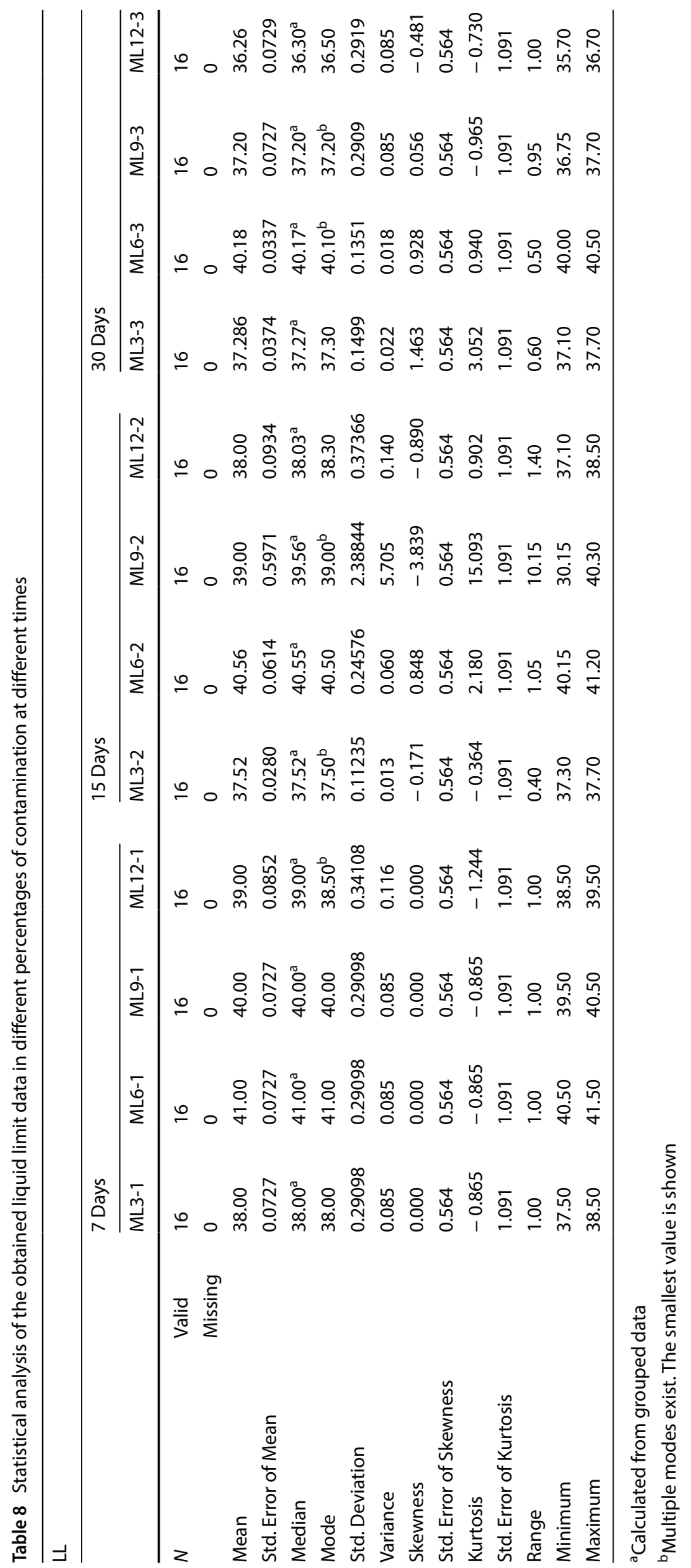




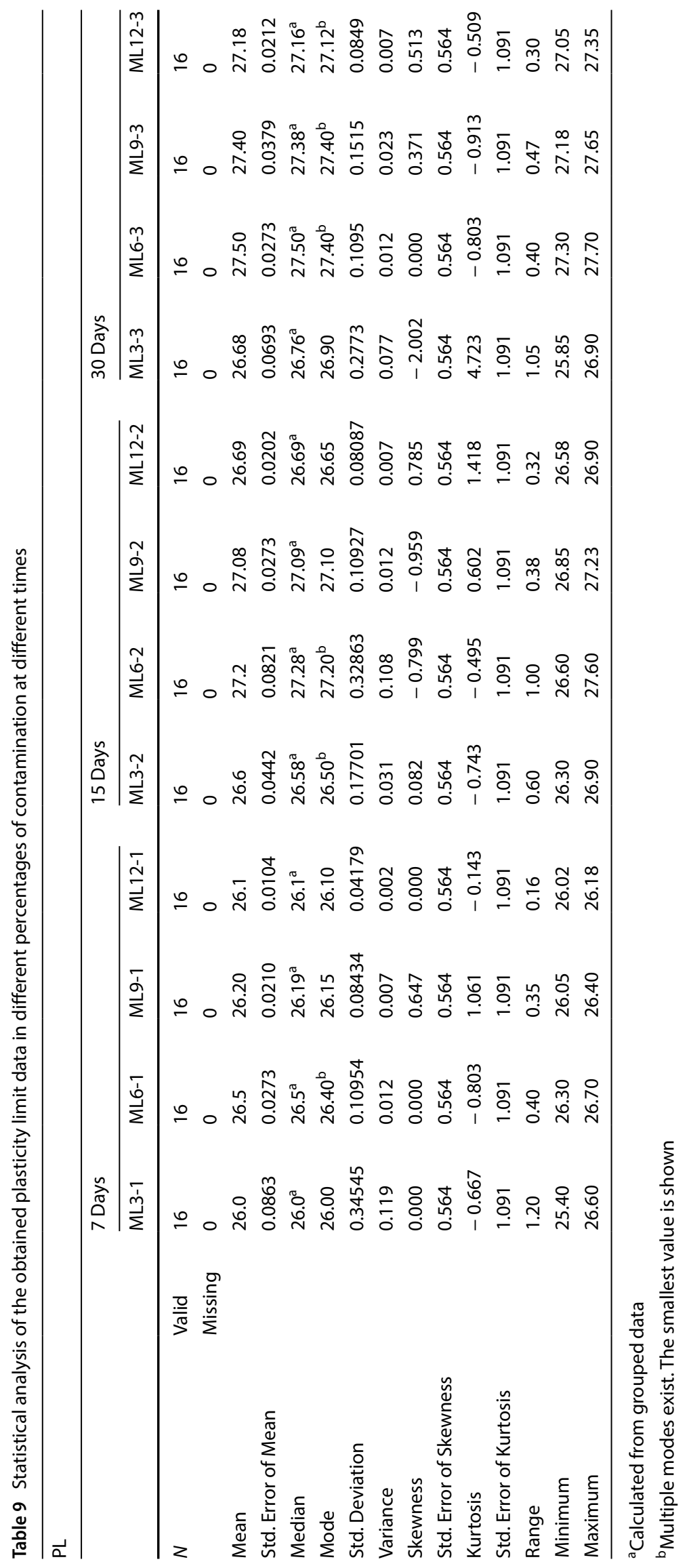


Fig. 10 Schematic of the gasoline-particle interaction model

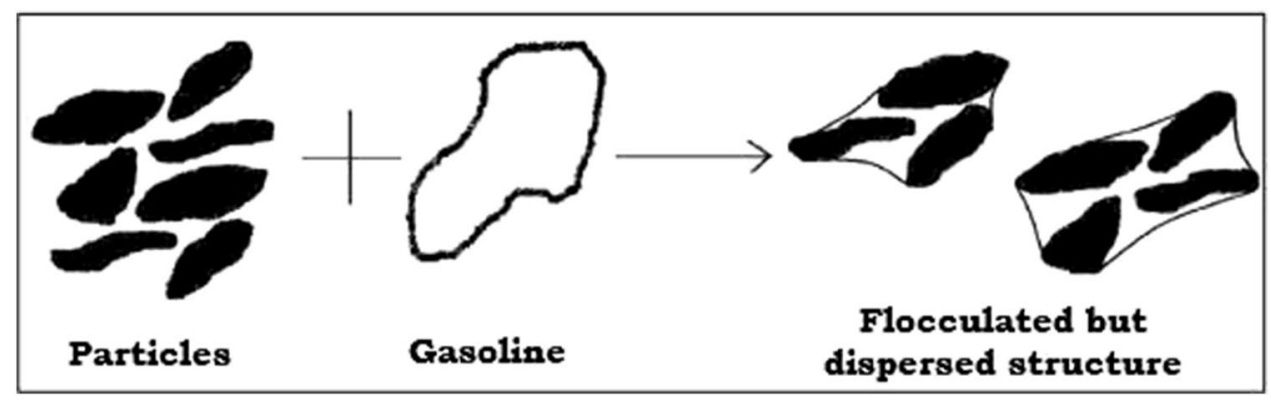

\section{Days aging Contaminated}

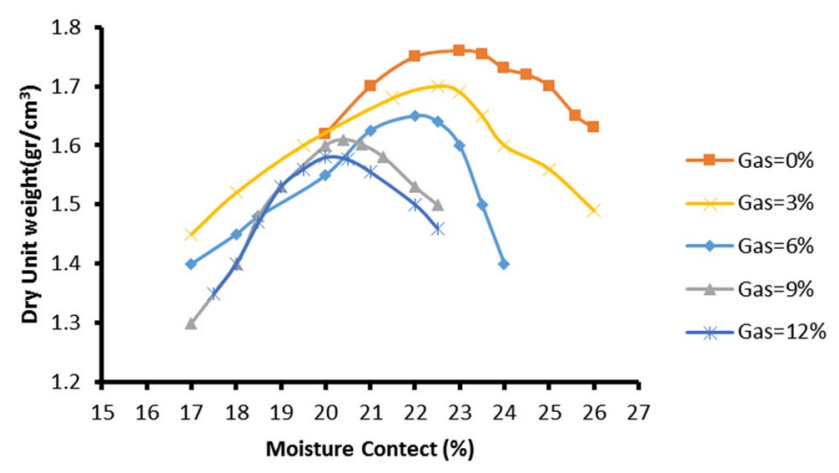

Fig. 11 Maximum dry density changes in 7-day contamination and different percentages of gasoline

\section{Days aging Contaminated}

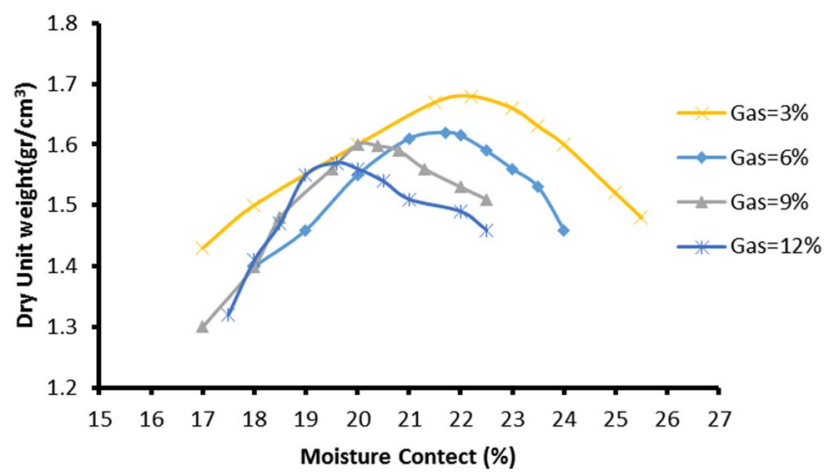

Fig. 12 Maximum dry density changes in 15-day contamination and different percentages of gasoline

is attributed to the low dielectric constant of hydrocarbon fluids such as gasoline. According to Lambe [65] and Sridharan and Rao [66], the cohesion of clay increases with a reduction in the dielectric constant of the pore fluid. Besides, Sharifi Teshnizi et al. [38] and Zhao [67] showed that the organic material and hydrocarbons reduce repulsive forces between clay particles resulting
30 Days aging Contaminated

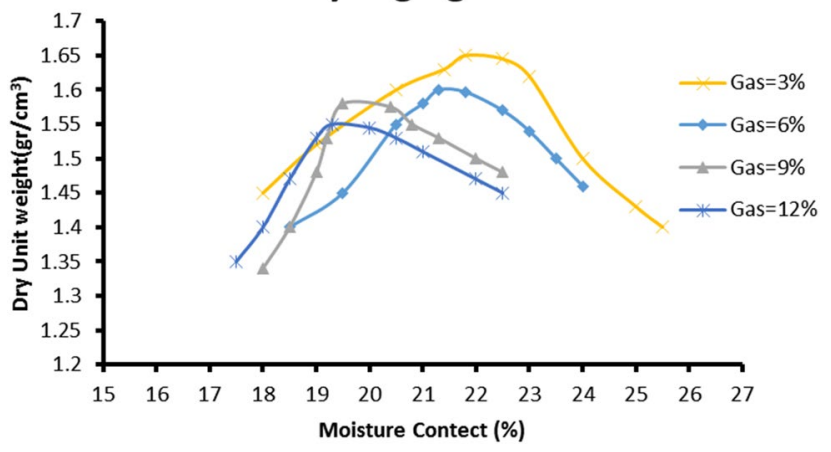

Fig. 13 Maximum dry density changes in 30-day contamination and different percentages of gasoline

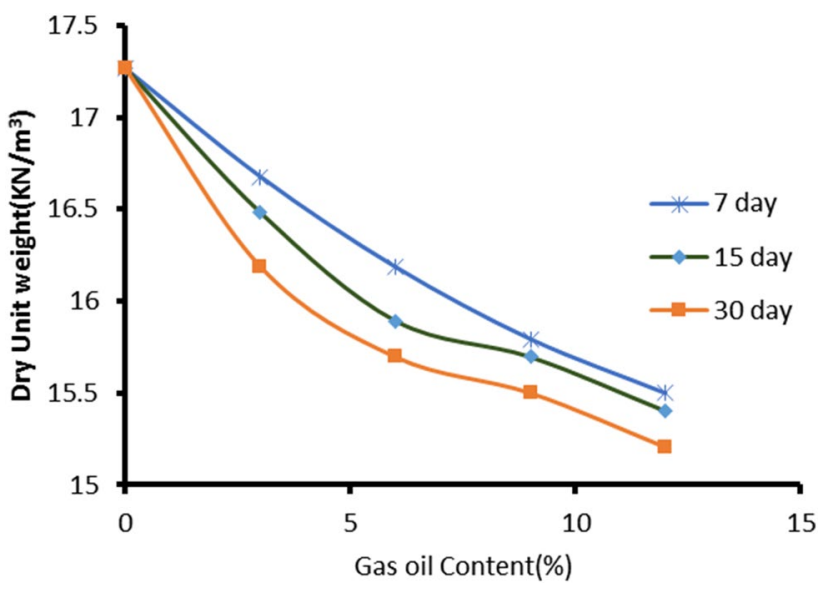

Fig. 14 Relationship between maximum dry density and gasoline content at the different ages

in higher cohesion. On the other hand, gasoline viscosity is higher than in water (Table 5). Therefore, the ability of gasoline to withstand the shear force is more than water. When shear force is applied to the samples, in addition to soil particles, gasoline resists shear force too, and apparent cohesion of the soil increases. The decrease in the friction angle in the presence of gasoline might be 


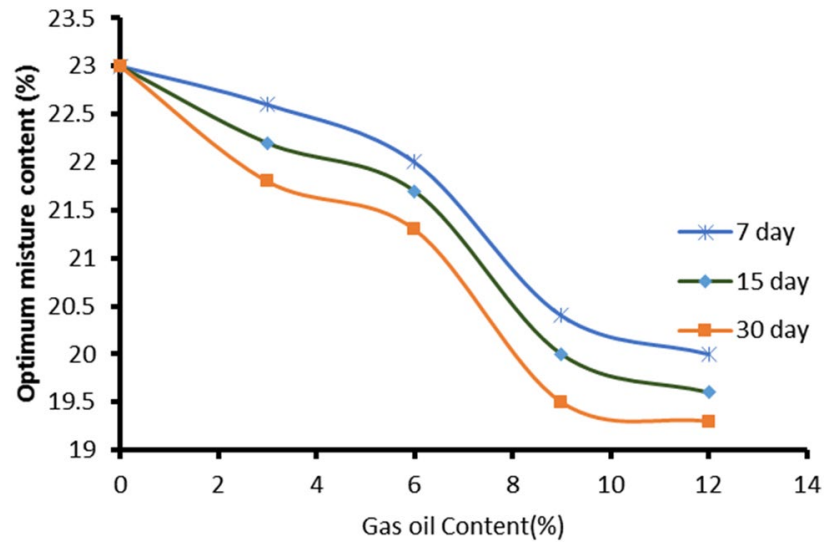

Fig. 15 Relationship between moisture and gasoline content at different ages

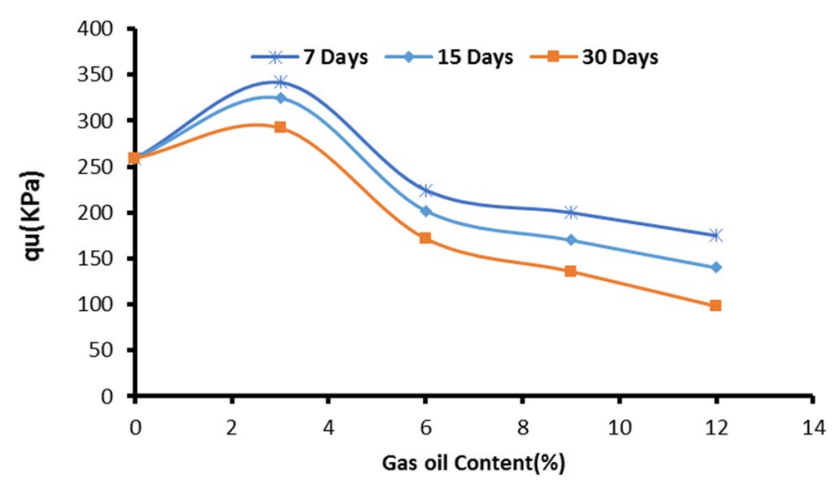

Fig. 16 Unconfined compressive strength variations at different gasoline contents and different ages

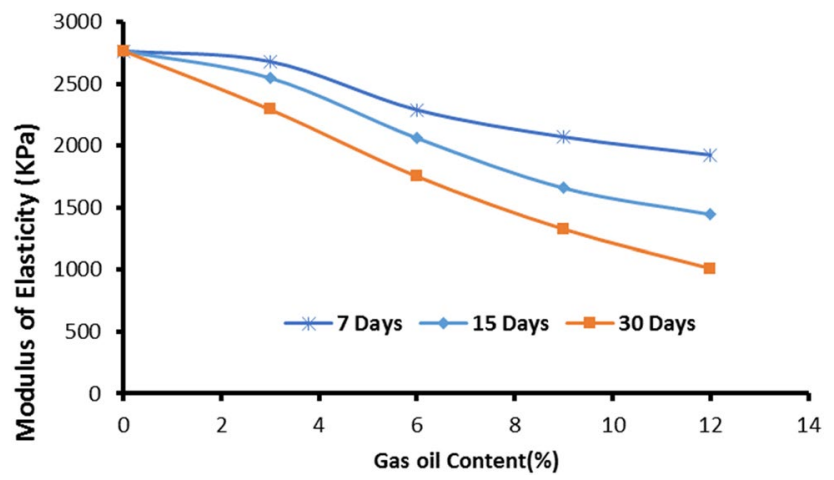

Fig. 17 Modulus of elasticity variations at different gasoline contents and different ages

associated with the lubrication effect of gasoline on the surface of the particles.

Tables 12 and 13 show the statistical analysis of the results of shear parameters (adhesion and internal friction angle) of different samples prepared with different percentages of contamination at different times.

\subsection{Numerical modeling}

The stability of any foundation depends on various factors such as bearing capacity and the amount of soil settlement under the foundation. Therefore, in this section, we present numerical analysis and modeling results of investigating the effects of contamination with $0,3,6,9$, and $12 \%$ of gasoline on geotechnical properties of the soil. Figure 20 shows the analyzed model.

Geotechnical parameters obtained from the laboratory results with different amounts of contamination over 7 days were analyzed. Figures 21 and 22 represent the rate of settlement changes for the soil without contamination and with $12 \%$ contamination, respectively. Also, Figs. 23 and 24 show the settlement and the percentage of shear strain changes below the foundation in different percentages of contamination, respectively.

The analysis results show that increasing the contamination content leads to consequent increases in the settlement, shear strain percentage, and ductility due to the changes in geotechnical parameters. These changes are completely consistent with the laboratory results.

Figures 25, 26, 27, 28, 29 illustrate the soil failure mechanism for different contamination percentages. The results show that increasing the amount of contamination changes the plastic points and failure mechanisms. Additionally, it is seen that the rate of soil elevation swelling failure varies depending on the amount of contamination.

\section{Discussion}

In this paper, the effects of contamination with gasoline on the geotechnical properties of ML soil were studied. Tests conducted for this purpose consisted of Atterberg limits, compaction, unconfined compression, and direct shear tests.

Results showed a decrease in the friction angle, maximum dry density, optimum moisture content, and UCT and an increase in the cohesion of silty soil with increasing the contamination content.

The results of compaction tests in this study, like those of Khamehchiyan et al. [15], Naseh et al. [29], reduced the maximum density and optimal moisture. One explanation for the similarity of the results can be the existence of almost similar soils, as the soil used in this research was silty or silty sandy soils. Meanwhile, the reason for the discrepancy between our results and the results of Rahman et al. $[17,59]$ was the use of clay in their research and the difference in the contaminant types. 


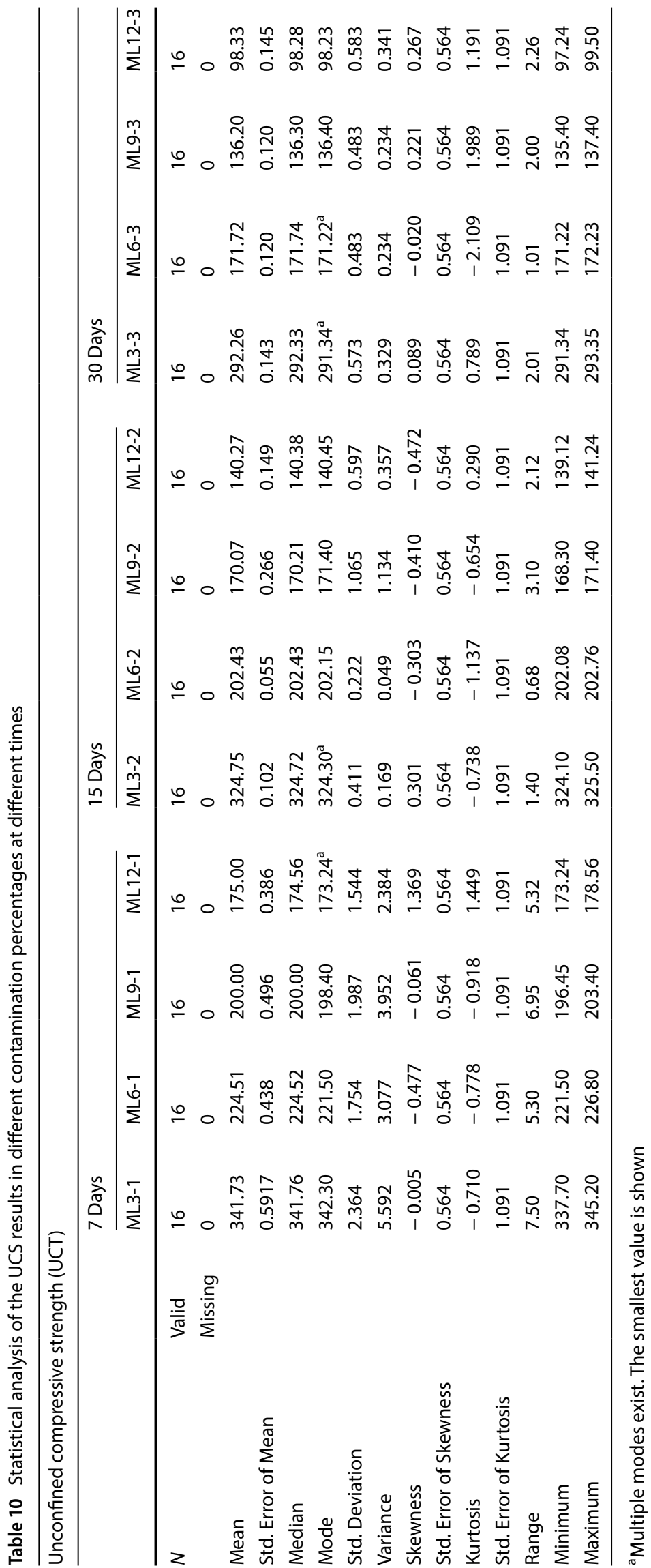




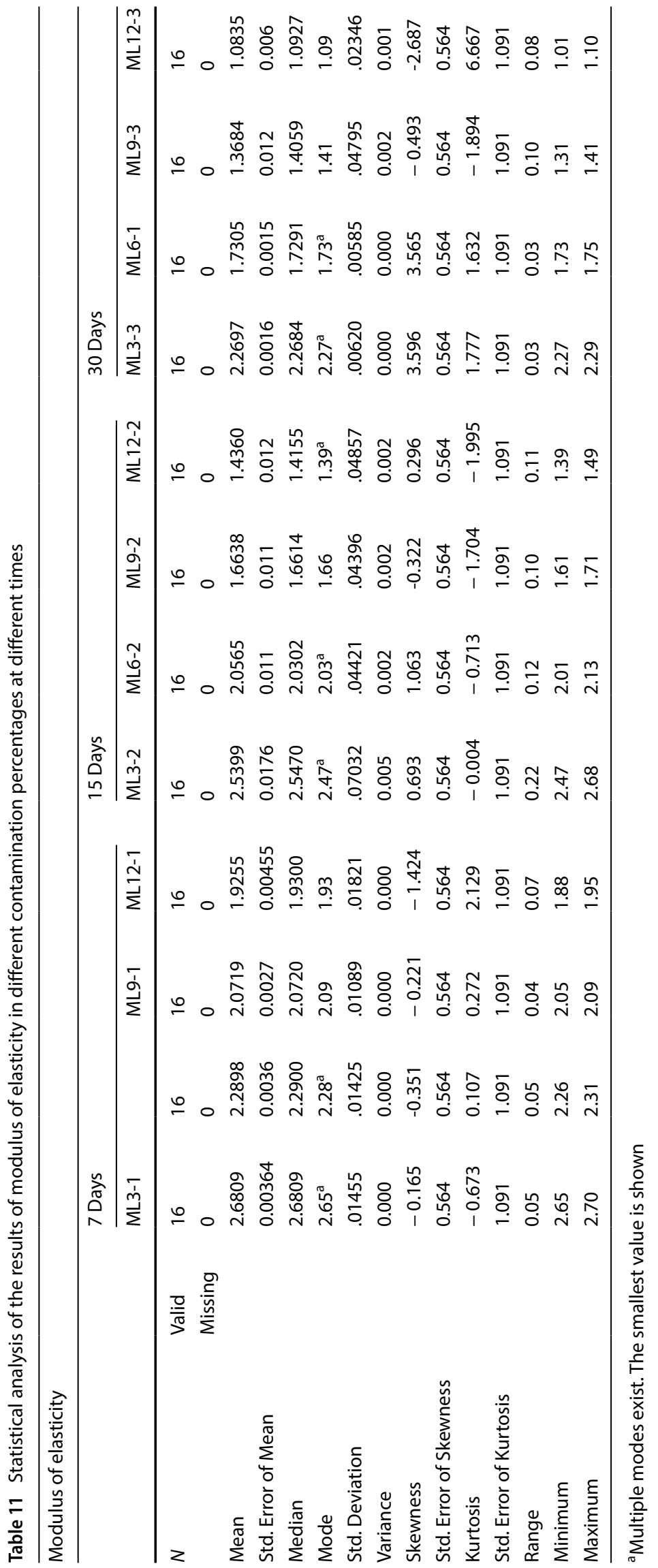




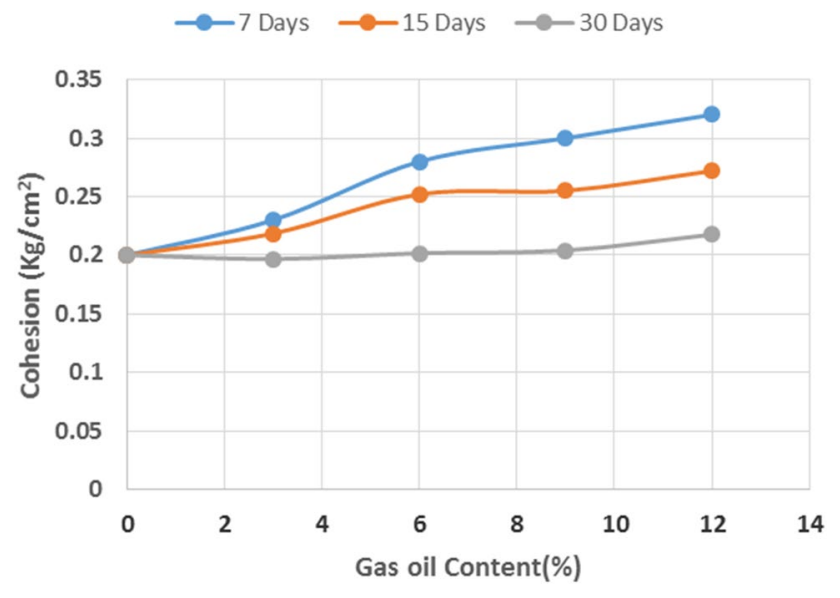

Fig. 18 Cohesion variations at different percentages of gasoline and different ages

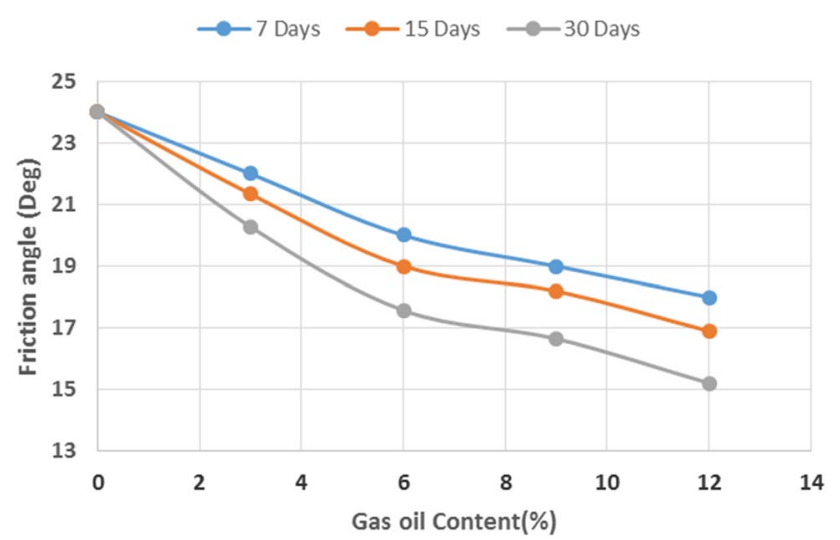

Fig. 19 Friction angle variations at different percentages of gasoline and different ages

Moreover, the results showed that increasing the contaminant percentage ( $>3 \%$ ) decreased the UCT of the soil. This result is consistent with those of Khamehchiyan et al. [15], Naseh et al. [29], Zhi-bin et al. [68], Eissa [69], Rodríguez Cuervo [70] and Aziz [1]. It is of note that in additives less than $3 \%$, the resistance increases slightly. This result is in line with the results of Khamehchiyan et al. [15]. This effect and its reason are shown in Fig. 10. Another noteworthy point is that diesel due to its nonpolar nature causes the formation of a flocculent structure in the soil (Fig. 10), thereby changing the soil plasticity properties [71]. Thus, more inter-cluster channels are formed in the soil texture, ultimately leading to a reduction in maximum dry density. Also, since diesel was added to the samples before adding water at different intervals (7, 15, and 30 days before), according to Rahman et al. [59] a thin layer of contaminant was present on the surface of the soil particles and adding a small amount of water also causes the weak bond between the particles to separate (Fig. 30). In this process, the diesel released into the pore fluid, due to its low density relative to water, takes more space and is a factor to reduce the amount of water needed to compress the samples. Furthermore, the formation of water-diesel emulsion, which is an aqueous phase for lower percentages of contaminant, will affect the density of contaminated soil due to the dual behavior of these two fluids and the insolubility of diesel in water.

Increasing the percentage of diesel contamination and the duration of contamination reduced the UCT values and the final strain of the contaminated samples. Increasing the amount of contamination changed the sample's behavior from the softening strain state to the hardening strain. The presence of diesel leads to a change in the hardening behavior of the samples at higher percentages of contaminant. The presence of organic fluid in the soil texture leads to the bonding of particles by weak van der Waals forces (physical absorption). Figure 31 presents the ductility changes of the studied samples. As can be seen, at higher percentages of contaminant, because of the higher viscosity of diesel compared to water, the internal friction angle between the particles and the possibility of grain slipping declines, especially in the coarse-grained part of the soil. This, in turn, reduces the UCS of the samples. This soil behavior is similar to the one reported by Ercoli et al. [72] (Fig. 31).

According to Al-Sanad and Ismael [73], the change in resistance of diesel-contaminated samples due to processing can be reflected as an increase in the rate of longterm reactions and the activity of soil particle surface due to being covered by diesel molecules. The reason is that, compared to water, diesel requires more time to react and adsorb. This event occurs due to changes in the $\mathrm{pH}$ of the fluid and a decrease in the hydration rate of ions. As a result, diesel molecules need more time to adsorb onto soil particles.

\section{Conclusion}

Based on the findings of this study, the following results were obtained:

- In fine-grained sediments, as gasoline contamination increases, the plastic limit decreases as well. Since gasoline molecules are non-polar, when the fine particles become contaminated, a thin layer of oil encloses the particles. This thin layer appears to prevent the water from reacting with the charged particles of clay.

- With increasing the gasoline percentage, the optimum moisture decreases because the added gasoline fills some 
Table 12 Statistical analysis of the results of adhesion values in different percentages of contamination at different times

The adhesion values (Cohesion)

\begin{tabular}{|c|c|c|c|c|c|c|c|c|c|c|c|c|c|}
\hline & & \multicolumn{4}{|l|}{7 Days } & \multicolumn{4}{|l|}{15 Days } & \multicolumn{4}{|c|}{30 Days } \\
\hline & & ML3-1 & ML6-1 & ML9-1 & ML12-1 & ML3-2 & ML6-2 & ML9-2 & ML12-2 & ML3-3 & ML6-3 & ML9-3 & ML12-3 \\
\hline \multirow[t]{2}{*}{$N$} & Valid & 16 & 16 & 16 & 16 & 16 & 16 & 16 & 16 & 16 & 16 & 16 & 16 \\
\hline & Missing & 0 & 0 & 0 & 0 & 0 & 0 & 0 & 0 & 0 & 0 & 0 & 0 \\
\hline Mean & & 0.23 & 0.28 & 0.30 & 0.32 & 0.22 & 0.25 & 0.255 & 0.271 & 0.197 & 0.201 & 0.208 & 0.220 \\
\hline Std. Error of Mean & & 0.0019 & 0.0013 & 0.0023 & 0.0010 & 0.0007 & 0.0009 & 0.0007 & 0.0009 & 0.0012 & 0.0001 & 0.001 & 0.001 \\
\hline Median & & 0.2311 & 0.2810 & 0.2985 & 0.3200 & 0.2186 & 0.2520 & 0.2540 & 0.2731 & 0.1963 & 0.2015 & 0.2084 & 0.2200 \\
\hline Mode & & $0.23^{a}$ & $0.28^{\mathrm{a}}$ & 0.31 & 0.32 & 0.22 & $0.25^{\mathrm{a}}$ & $0.25^{\mathrm{a}}$ & 0.27 & 0.19 & 0.20 & 0.20 & $0.22^{\mathrm{a}}$ \\
\hline Std. Deviation & & 0.0073 & 0.0051 & 0.009 & 0.0041 & 0.0027 & 0.0035 & 0.0026 & 0.0037 & 0.0047 & 0.0004 & 0.005 & 0.004 \\
\hline Variance & & 0.000 & 0.000 & 0.000 & 0.000 & 0.000 & 0.000 & 0.000 & 0.000 & 0.000 & 0.000 & 0.000 & 0.000 \\
\hline Skewness & & -0.279 & -0.662 & 0.534 & 0.111 & 0.858 & 0.810 & 1.291 & -1.815 & 1.176 & 0.896 & 1.158 & 0.219 \\
\hline Std. Error of Skewness & & 0.564 & 0.564 & 0.564 & 0.564 & 0.564 & 0.564 & 0.564 & 0.564 & 0.564 & 0.564 & 0.564 & 0.564 \\
\hline Kurtosis & & -1.310 & -0.612 & -1.223 & -1.155 & -0.715 & -0.305 & 1.413 & 2.256 & 0.917 & 0.682 & 0.893 & -1.238 \\
\hline Std. Error of Kurtosis & & 1.091 & 1.091 & 1.091 & 1.091 & 1.091 & 1.091 & 1.091 & 1.091 & 1.091 & 1.091 & 1.091 & 1.091 \\
\hline Range & & 0.02 & 0.02 & 0.03 & 0.01 & 0.01 & 0.01 & 0.01 & 0.01 & 0.02 & 0.00 & 0.02 & 0.01 \\
\hline Minimum & & 0.22 & 0.27 & 0.29 & 0.31 & 0.22 & 0.25 & 0.25 & 0.26 & 0.19 & 0.20 & 0.20 & 0.21 \\
\hline Maximum & & 0.24 & 0.29 & 0.32 & 0.33 & 0.23 & 0.26 & 0.26 & 0.27 & 0.21 & 0.20 & 0.22 & 0.23 \\
\hline
\end{tabular}

${ }^{\text {a }}$ Multiple modes exist. The smallest value is shown

Table 13 Statistical analysis of the results of internal friction angle in different percentages of contamination at different times

The internal friction angle

\begin{tabular}{|c|c|c|c|c|c|c|c|c|c|c|c|c|c|}
\hline & & \multicolumn{4}{|l|}{7 Days } & \multicolumn{4}{|l|}{15 Days } & \multicolumn{4}{|c|}{30 Days } \\
\hline & & ML3-1 & ML6-1 & ML9-1 & ML12-1 & ML3-2 & ML6-2 & ML9-2 & ML12-2 & ML3-3 & ML6-3 & ML9-3 & ML12-3 \\
\hline \multirow[t]{2}{*}{$N$} & Valid & 16 & 16 & 16 & 16 & 16 & 16 & 16 & 16 & 16 & 16 & 16 & 16 \\
\hline & Missing & 0 & 0 & 0 & 0 & 0 & 0 & 0 & 0 & 0 & 0 & 0 & 0 \\
\hline Mean & & 22.03 & 20.09 & 19.00 & 17.96 & 21.44 & 19.36 & 18.42 & 16.89 & 20.52 & 17.59 & 16.65 & 15.51 \\
\hline Std. Error of Mean & & 0.111 & 0.097 & 0.062 & 0.081 & 0.036 & 0.086 & 0.081 & 0.071 & 0.039 & 0.061 & 0.075 & 0.064 \\
\hline Median & & 22.01 & 20.04 & 19.00 & 18.00 & 21.44 & 19.38 & 18.40 & 16.89 & 20.50 & 17.59 & 16.68 & 15.50 \\
\hline Mode & & $21.60^{\mathrm{a}}$ & $19.90^{\mathrm{a}}$ & $18.90^{\mathrm{a}}$ & 18.30 & $21.40^{\mathrm{a}}$ & $19.00^{\mathrm{a}}$ & 18.90 & $16.50^{\mathrm{a}}$ & $20.40^{\mathrm{a}}$ & $17.30^{\mathrm{a}}$ & 16.90 & 15.30 \\
\hline Std. Deviation & & 0.445 & 0.387 & 0.248 & 0.324 & 0.143 & 0.343 & 0.323 & 0.285 & 0.159 & 0.244 & 0.301 & 0.256 \\
\hline Variance & & 0.198 & 0.150 & 0.061 & 0.105 & 0.021 & 0.118 & 0.104 & 0.081 & 0.025 & 0.060 & 0.091 & 0.066 \\
\hline Skewness & & -0.159 & 0.288 & -0.127 & -0.232 & -1.810 & -0.289 & 0.308 & 0.134 & 1.812 & -0.249 & -0.353 & 0.817 \\
\hline Std. Error of Skewness & & 0.564 & 0.564 & 0.564 & 0.564 & 0.564 & 0.564 & 0.564 & 0.564 & 0.564 & 0.564 & 0.564 & 0.564 \\
\hline Kurtosis & & -1.775 & -.717 & -0.007 & -1.447 & 5.326 & -0.701 & -1.221 & -1.097 & 5.531 & -0.248 & -1.076 & -0.211 \\
\hline Std. Error of Kurtosis & & 1.091 & 1.091 & 1.091 & 1.091 & 1.091 & 1.091 & 1.091 & 1.091 & 1.091 & 1.091 & 1.091 & 1.091 \\
\hline Range & & 1.20 & 1.30 & 0.90 & 0.90 & 0.60 & 1.20 & 0.90 & 0.80 & 0.73 & 0.90 & 0.94 & 0.80 \\
\hline Minimum & & 21.40 & 19.50 & 18.50 & 17.50 & 21.00 & 18.70 & 18.00 & 16.50 & 20.27 & 17.10 & 16.10 & 15.20 \\
\hline Maximum & & 22.60 & 20.80 & 19.40 & 18.40 & 21.60 & 19.90 & 18.90 & 17.30 & 21.00 & 18.00 & 17.04 & 16.00 \\
\hline
\end{tabular}

${ }^{\text {a }}$ Multiple modes exist. The smallest value is shown

of the empty spaces in the soil. Therefore, the peak point of the compaction curve is achievable with less water. Since the specific gravity of the gasoline is lower than that of water, in contaminated samples, the specific unit weight of the soil decreases with an increase in contami- nation content. The reason is that in dense samples, the pores are filled with gasoline instead of water.

- The results of the direct shear test show that increasing the time of contamination and the percentage of contamination results in a decrease in cohesion and the internal 


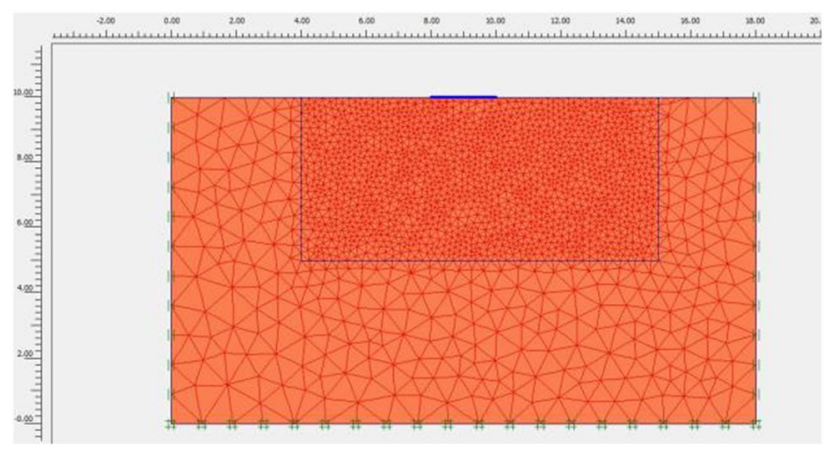

Fig. 20 Analysis model

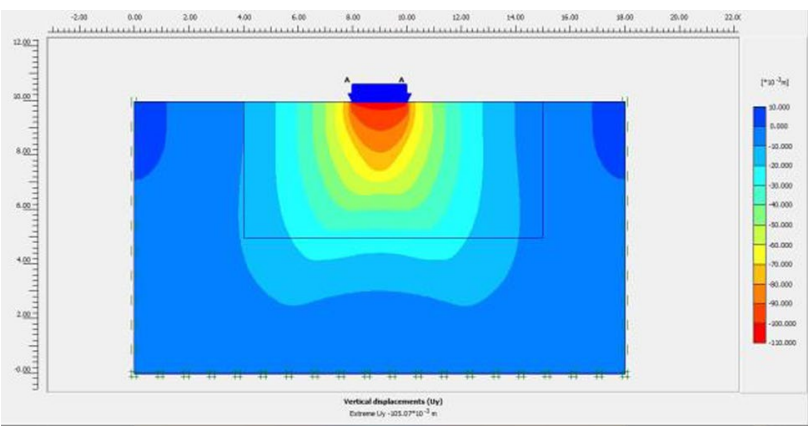

Fig. 21 Soil settlement under the foundation in soil without contamination

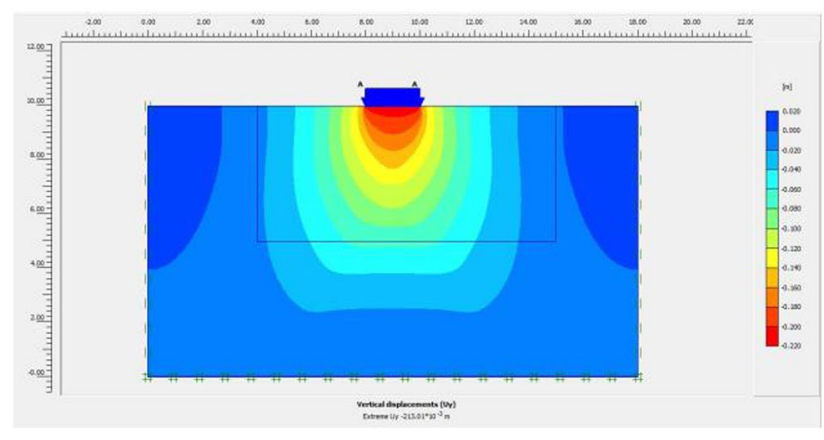

Fig. 22 Settlement under foundation for soil with $12 \%$ contamination

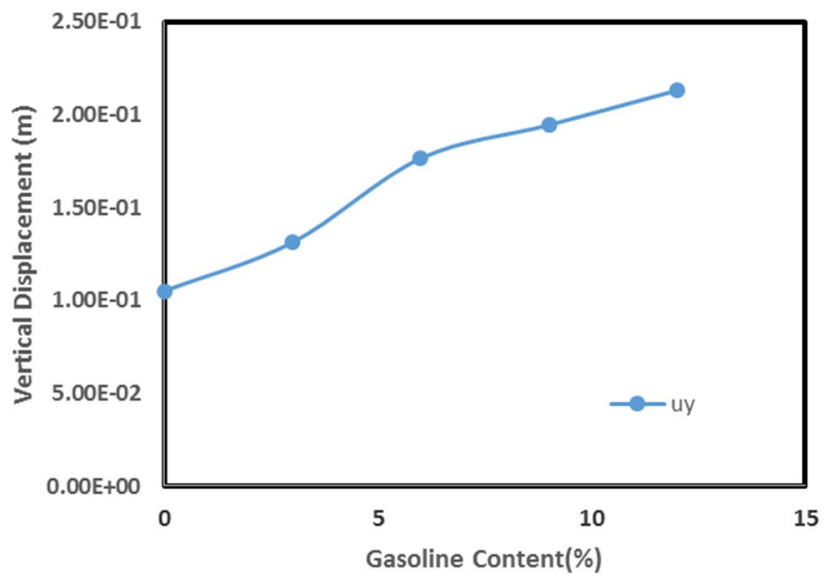

Fig. 23 Settlement changes for soil with different contamination amounts

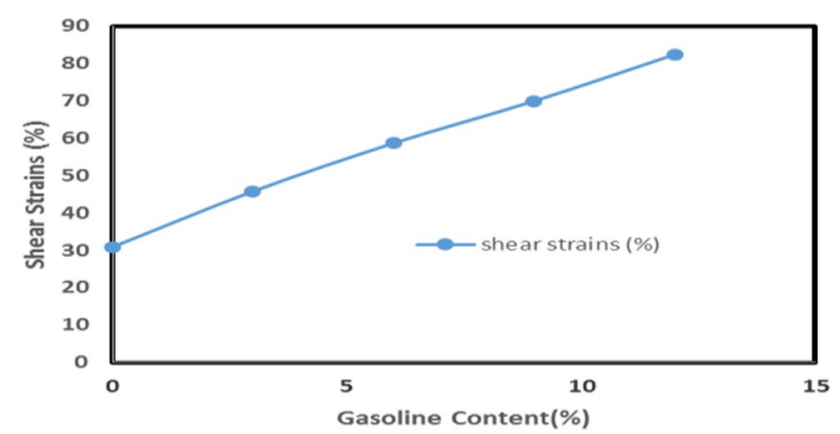

Fig. 24 Shear strain changes for soil with different contamination amounts

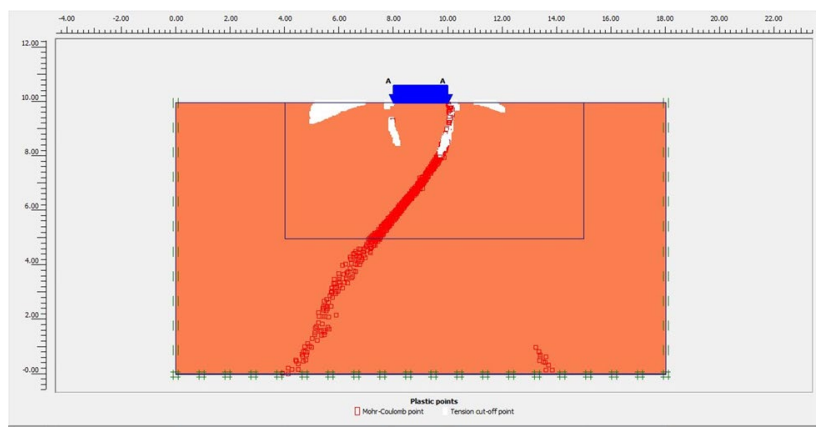

Fig. 25 Plastic points changes for the failed soil without contamination 


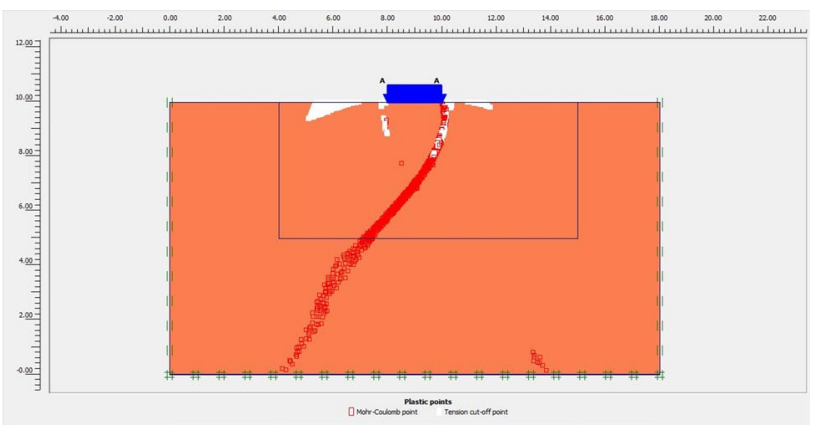

Fig. 26 Plastic points changes for the failed soil with $3 \%$ gasoline

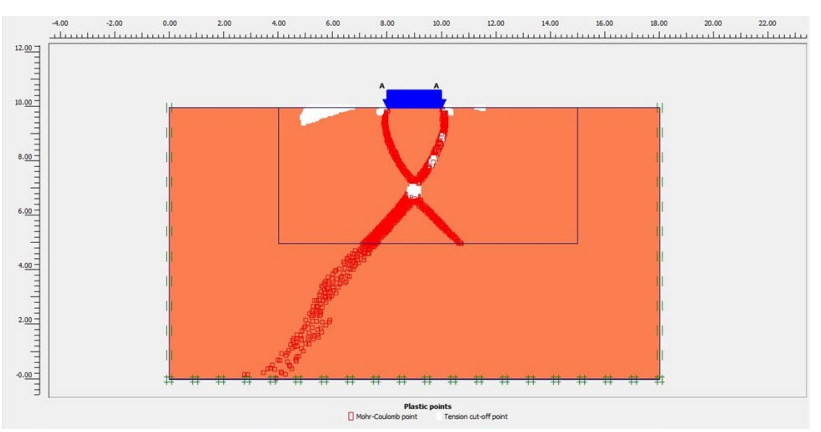

Fig. 27 Plastic points changes for the failed soil with $6 \%$ gasoline

friction angle of the soil. This reducing effect was greater on cohesion than the reduction in friction angle. It can be stated that the inter-particle encapsulation increases the slippery rate between the particles, thereby reducing the friction angle and cohesion of the soil particles.

- Petroleum hydrocarbons, such as gasoline, surround the soil particles, making them non-polar and insulating them against water molecules. This results in the change of water state from the adsorption state to an inter-grained state so the pore pressure increases. Increasing pore pressure reduces soil strength and elastic modulus and increases soil deformability

- The reason for the decrease in shear stress can be due to the combination of the physical and chemical effects of gasoline. Physically, the presence of gasoline causes better

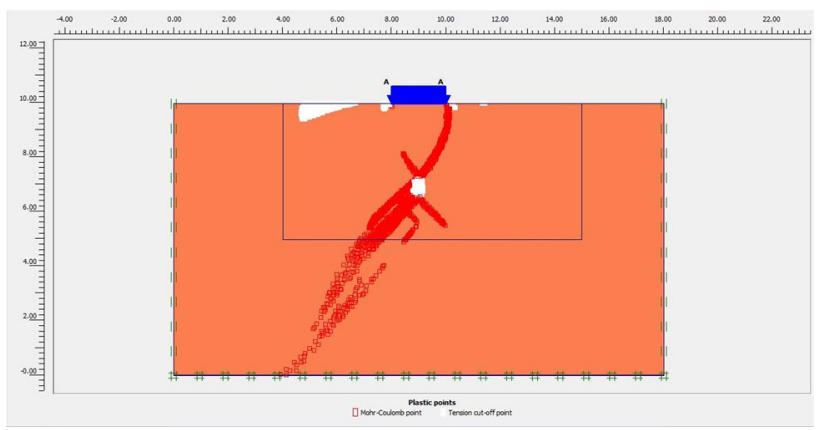

Fig. 28 Plastic points changes for the failed soil with $9 \%$ gasoline

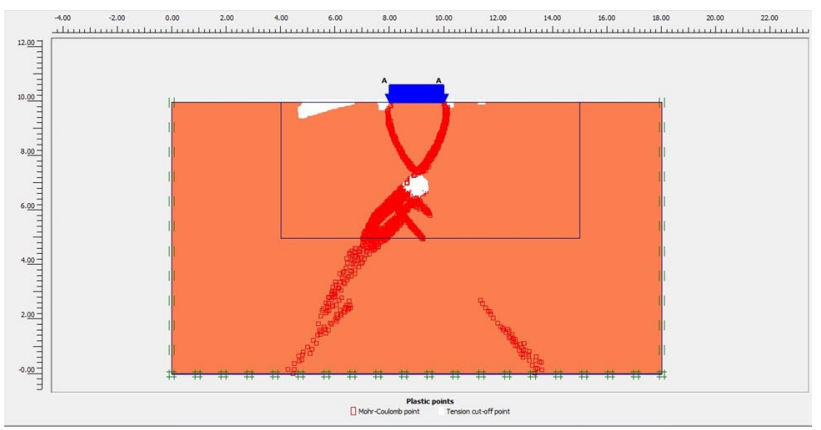

Fig. 29 Plastic points changes for the failed soil with $12 \%$ gasoline

slipping between the grains during shear and reduces soil shear stress. But from a chemical point of view, due to the hydrophilicity of the fine particles, swelling of the finegrained soil with water absorption is greater than that of gasoline.

- This paper demonstrated the effects of contamination duration on the soil geotechnical properties. The results showed that increasing the duration of soil exposure to contamination led to a drastic reduction in geotechnical properties such as dry density, optimum moisture content, compressive strength, elastic modulus, and shear parameters. However, the degradation rate of these parameters in 30 days is much higher than in 7 days.

- Results of the numerical analysis showed that the changes in settling and shear strain percentage have increased 
Fig. 30 Separation and behavior of contaminated soil by adding water
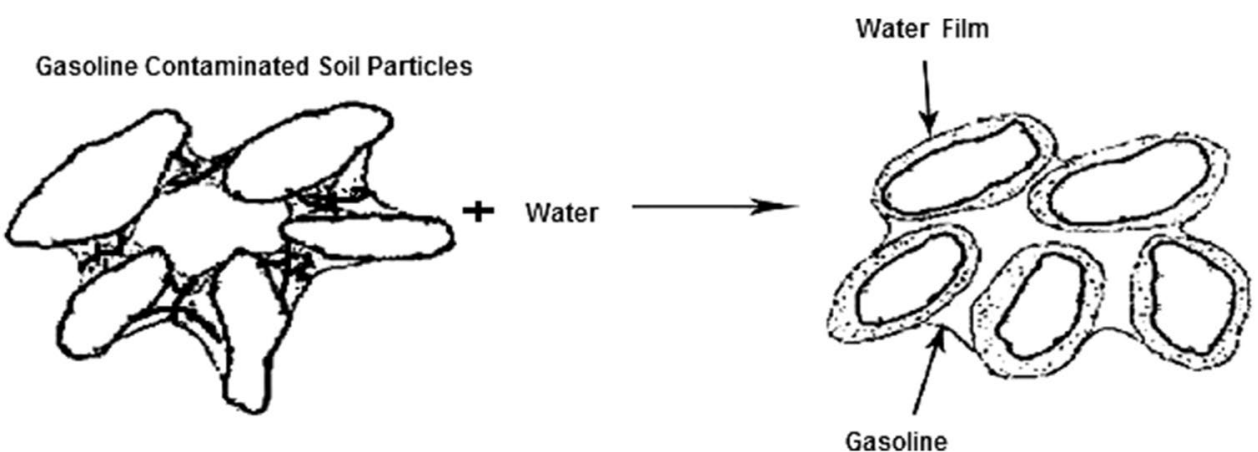

Gasoline
Fig. 31 Schematic of the change in the behavior of the fine-grained part of the studied soil to granular due to diesel contamination
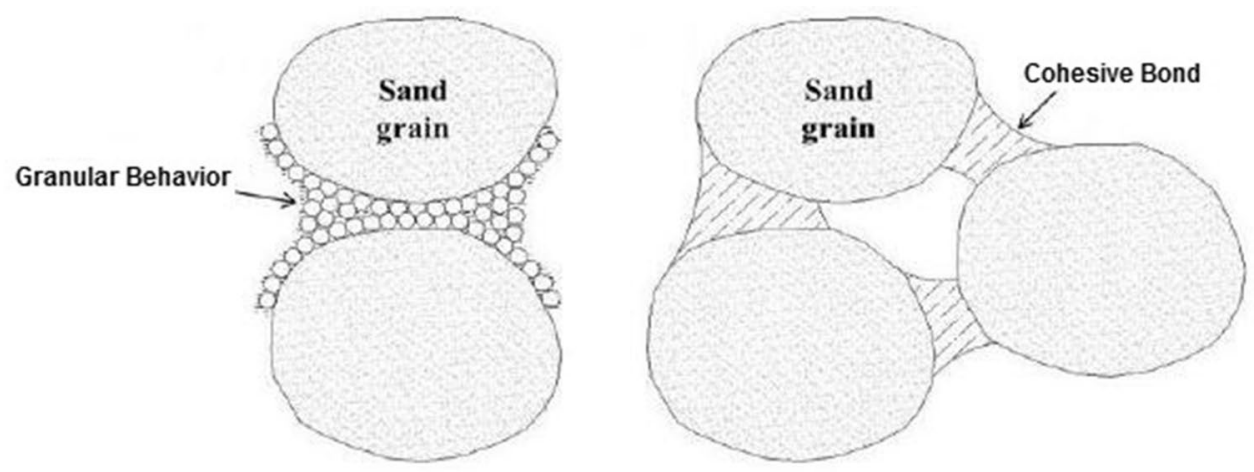

with increasing contamination percentage, which is completely consistent with the laboratory results.

- In general, it can be concluded that low percentages of contamination do not affect soil's engineering properties. However, when this percentage is more than about $4 \%$, it can decrease the engineering properties of the soil.

Acknowledgements This work is based on the results from the master's thesis titled "Effect of diesel oil contaminant on geotechnical properties of silty soils" guided and written at the Islamic Azad University of Kahnooj branch, Iran. The authors appreciate the Head of Soil and Rock Mechanics Laboratory of EDP Company, Dr. Ebrahim Sharifi Teshnizi, for his cooperation in this research.

\section{Declarations}

Conflict of interest The authors declare that they have no conflict of interest.

Open Access This article is licensed under a Creative Commons Attribution 4.0 International License, which permits use, sharing, adaptation, distribution and reproduction in any medium or format, as long as you give appropriate credit to the original author(s) and the source, provide a link to the Creative Commons licence, and indicate if changes were made. The images or other third party material in this article are included in the article's Creative Commons licence, unless indicated otherwise in a credit line to the material. If material is not included in the article's Creative Commons licence and your intended use is not permitted by statutory regulation or exceeds the permitted use, you will need to obtain permission directly from the copyright holder. To view a copy of this licence, visit http://creativecommons. org/licenses/by/4.0/.

\section{References}

1. Aziz S (2019) Production and characterization of biochar from organic waste and its application for bioremediation in diesel contaminated soils, Ph.D. Thesis, Department of Microbiology Faculty of Biological Sciences, Quaid-i-Azam University Isalamabad, Pakistan, $246 \mathrm{p}$

2. Sharifi Teshnizi E, Arjmandzadeh R, Rastegarnia A, Bakhshi A (2019) Geogrid design in soil improvement, Azarin Mehr Publisher, Iran, 158 P, ISBN: 9786226855136

3. Yazdi A, Ashja Ardalan A, Emami MH, Dabiri R, Foudazi M (2019) Magmatic interactions as recorded in plagioclase phenocrysts of quaternary volcanics in SE Bam (SE Iran). Iran J Earth Sci 11(3):215-225

4. Nazemi E, Arian MA, Jafarian A, Pourkermani M, Yazdi A (2019) Studying the Genesis of Igneous Rocks in Zarin-Kamar Region (Shahrood, Northeastern Iran) by Rare Earth Elements. Revista Gênero e Direito 8(4):446-466. https://doi.org/10.22478/ufpb. 2179-7137.2019v8n4.48442

5. Croney D, Croney P (1991) The design and performance of road pavements. McGraw-Hill, New York

6. Meegoda JN, Chen B, Gunasekera SD, Pederson P (1998) Compaction characteristics of contaminated soils-reuse as a road base material. In: Vipulanandan C, Elton David J (eds) Recycled materials in geotechnical applications, vol 79. Geotechnical Special Publication ASCE, pp 165-209 
7. Meegoda JN (1999) Stabilization/solidification of petroleumcontaminated soils with asphalt emulsions. Pract Period Hazardous Toxic Radioact Waste Manag 3:46-55

8. Evgin E, Das BM (1992) Mechanical behavior of an oil contaminated sand. In: Mediterranean conference on environmental geotechnology. A.A. Balkema, Rotterdam, Netherlands, pp 101-108. http://pascal-francis.inist.fr/vibad/index.php?action= getRecordDetail\&idt $=6544767$

9. Cook EE, Puri VK, Shin EC (1992, January) Geotechnical characteristics of crude oil-contaminated sands. In:The Second International Offshore and Polar Engineering Conference. International Society of Offshore and Polar Engineers. San Francisco, California, USA, June 1992. https://onepetro.org/ISOPEIOPEC/ proceedings-abstract/ISOPE92/All-ISOPE92/ISOPE-I-92-053/ 22673

10. Al-Sanad HA, Eid WK, Ismael NF (1996) Geotechnical properties of oil-contaminated Kuwaiti sand. Int J Rock Mech Min Sci Geomech Abstr. 33:A116. https://doi.org/10.1016/01489062(96)86986-5

11. Shin EC, Lee JB, Das BM (1999) Bearing capacity of a model scale footing on crude oil-contaminated sand. Geotech Geol Eng 17(2):123-132. https://doi.org/10.1023/A:1016078420298

12. Shin EC, Lee JB, Das BM (1999) Bearing capacity of a model scale footing on crude oil-contaminated sand. Geotech Geol Eng 17(2): 123-132. https://doi.org/10.1023/A:1016078420298

13. Puri VK (2000) Geotechnical aspects of oil-contaminated sands. Soil Sediment Contam 9:359-374. https://doi.org/10.1080/ 10588330091134301

14. Rodriguez OR (2004). Influence of oil contamination of geotechnical properties of silty sand. M.Sc Thesis, University of Alberta,Canada. https://elibrary.ru/item.asp?id=9367191

15. Khamehchiyan M, Hossein Charkhabi A, Tajik M (2007) Effects of crude oil contamination on geotechnical properties of clayey and sandy soils. Eng Geol 89:220-229. https://doi.org/10.1016/j. enggeo.2006.10.009

16. Nasr AMA (2009) Experimental and theoretical studies for the behavior of strip footing on oil-contaminated sand. J Geotech Geoenviron Eng 135:1814-1822. https://doi.org/10.1061/(asce) gt.1943-5606.0000165

17. Rahman ZA, Hamzah U, Taha MR, Ithnain NS, Ahmad N (2010) Influence of oil contamination on geotechnical properties of basaltic residual soil. Am J Appl Sci 7:954

18. Di Matteo L, Bigotti F, Ricco R (2011) Compressibility of kaolinitic clay contaminated by ethanol-gasoline blends. J Geotech Geoenviron Eng 137:846-849. https://doi.org/10.1061/(asce) gt.1943-5606.0000494

19. Jia YG, Wu Q, Shang H, Yang ZN, Shan HX (2011) The influence of oil contamination on the geotechnical properties of coastal sediments in the Yellow River Delta. China Bull Eng Geol Environ 70:517-525. https://doi.org/10.1007/s10064-011-0349-8

20. Ijimdiya T, Igboro $T$ (2012) The compressibility behavior of oil contaminated soils. Electron J Geotech Eng 17(10):3553-3562

21. Kermani M, Ebadi T (2012) The effect of oil contamination on the geotechnical properties of fine-grained soils. Soil Sediment Contam 21:655-671. https://doi.org/10.1080/15320383. 2012.672486

22. Alhassan HM, Fagge SA (2013) Effects of crude oil, low point pour fuel oil and vacuum gas oil contamination on the geotechnical properties of sand, clay and laterite soils. Int J Eng Res Appl 3:1947-1954

23. Khan SR, Kumar JN, Kumar RN, Patel JG (2013) An assessment of physicochemical properties, heavy metal enrichment and fungal characterization of refined kerosene impacted soil in Anand, Gujarat. India Int J Environ 2:164-174. https://doi.org/ 10.3126/ije.v2i1.9219
24. Khosravi E, Ghasemzadeh H, Sabour MR, Yazdani H, Reza M, Yazdani H (2013) Geotechnical properties of gas oil-contaminated kaolinite. Eng Geol 166:11-16. https://doi.org/10. 1016/j.enggeo.2013.08.004

25. Ota JO (2013) The effect of light crude oil contamination on the geotechnical properties of kaolinite clay soil. Doctoral thesis, Anglia Ruskin University., 345 p. http://arro.anglia.ac. uk/id/eprint/297120

26. Singh SK, Srivastava RK, John S (2008) Settlement characteristics of clayey soils contaminated with petroleum hydrocarbons. Soil Sediment Contam 17:290-300. https://doi.org/10. 1080/15320380802007028

27. Estabragh AR, Beytolahpour I, Moradi M, Javadi AA (2014) Consolidation behavior of two fine-grained soils contaminated by glycerol and ethanol. Eng Geol 178:102-108. https://doi.org/10. 1016/j.enggeo.2014.05.017

28. Abousnina RM, Manalo A, Shiau J, Lokuge W (2015) Effects of light crude oil contamination on the physical and mechanical properties of fine sand. Soil Sediment Contam 24:833-845. https://doi.org/10.1080/15320383.2015.1058338

29. Nasehi SA, Uromeihy A, Nikudel MR, Morsali A (2016) Influence of gas oil contamination on geotechnical properties of fine and coarse-grained soils. Geotech Geol Eng 34:333-345. https://doi. org/10.1007/s10706-015-9948-7

30. Harsh G, Patel A, Himanshu B, Tiwari P (2016) Effect of rate of crude oil contamination on index properties and engineering properties of clays and sands. Indian J Sci Technol. https://doi. org/10.17485/ijst/2016/v9i30/99193

31. Al-Adili A, Alsoudany KY, Shakir A (2017) Investigation of crude oil pollution effect on stiffness characteristics of sandy and gypseous soil. Soil Mech Found Eng 54:276-282. https://doi.org/10. 1007/s11204-017-9469-x

32. Karkush MO, Kareem ZA (2017) Investigation the impacts of fuel oil on the geotechnical properties of cohesive soil. Eng J 21:127-137. https://doi.org/10.4186/ej.2017.21.4.127

33. Shahidi M, Farrokhi F, Asemi F (2019) Changes in physical and mechanical properties of gas oil-contaminated clayey sand after addition of clay nanoparticles. J Environ Eng 145:04019004. https://doi.org/10.1061/(asce)ee.1943-7870.0001508

34. Nwachukwu AN, Okoro BC, Osuagwu JC, Nwakwasi NL, Onyechere IC (2020) Index and compaction properties of oil contaminated clay soils in Niger-Delta Region of Nigeria. Saudi J Eng Technol 05:81-85. https://doi.org/10.36348/sjet.2020. v05i02.007

35. Ostovar M, Ghiassi R, Mehdizadeh MJ, Shariatmadari N (2020) Effects of crude oil on geotechnical specification of Sandy Soils. Soil Sediment Contam 00:1-16. https://doi.org/10.1080/15320 383.2020.1792410

36. Salimnezhad A, Soltani-Jigheh H, Soorki AA (2021) Effects of oil contamination and bioremediation on geotechnical properties of highly plastic clayey soil. J Rock Mech Geotech Eng. https:// doi.org/10.1016/j.jrmge.2020.11.011

37. Nwankwegu AS, Onwosi CO (2017) Bioremediation of gasoline contaminated agricultural soil by bioaugmentation. Environ Technol Innov 7:1-11. https://doi.org/10.1016/j.eti.2016.11.003

38. Sharifi Teshnizi E, Reisi Dehkordi MS, Moaiede Kia AH (2020) Environmental effects of hydrocarbon pollution on soil and water, Supreme National Defense University, Tehran, Iran, 402 p, ISBN: 978-622-248101-8

39. Poorbehzadi K, Yazdi A, Teshnizi ES, Dabiri R (2019) Investigating of Geotechnical Parameters of Alluvial Foundation in Zaram-Rud Dam Site, North Iran. Int J Min Eng Technol 1(1):33-44

40. Feng $D$, Aldrich $C$ (2000) Sonochemical treatment of simulated soil contaminated with diesel. Adv Environ Res 4:103-112. https://doi.org/10.1016/S1093-0191(00)00008-3 


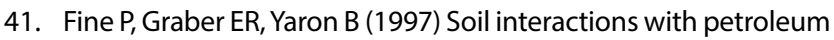
hydrocarbons: abiotic processes. Soil Technol 10:133-153

42. ASTM D1556-07 (2007) Standard Test Method for Density and Unit Weight of Soil in Place by the Sand-Cone Method, ASTM International, West Conshohocken, PA. www.astm.org. https:// doi.org/10.1520/D1556-07

43. ASTM D422-63 (2007) Standard Test Method for Particle-Size Analysis of Soils, ASTM International, West Conshohocken, PA, 2007. www.astm.org. https://doi.org/10.1520/D0422-63R07

44. ASTM D4318-17 (2017) Standard Test Methods for Liquid Limit, Plastic Limit, and Plasticity Index of Soils, ASTM International, West Conshohocken, PA, www.astm.org. https://doi.org/10. 1520/D4318-17

45. ASTM D2487-17 (2017) Standard Practice for Classification of Soils for Engineering Purposes (Unified Soil Classification System), ASTM International, West Conshohocken, PA, 2017. www. astm.org. https://doi.org/10.1520/D2487-17

46. ASTM D854-14 (2014) Standard Test Methods for Specific Gravity of Soil Solids by Water Pycnometer, ASTM International, West Conshohocken, PA. www.astm.org. https://doi.org/10.1520/ D0854-14

47. ASTM D2166 (2016) Standard Test Method for Unconfined Compressive Strength of Cohesive Soil, ASTM International, West Conshohocken, PA, 2016. www.astm.org. https://doi.org/10. 1520/D2166_D2166M-16

48. ASTM D2216-19 (2019) Standard Test Methods for Laboratory Determination of Water (Moisture) Content of Soil and Rock by Mass, ASTM International, West Conshohocken, PA, 2019. www. astm.org. https://doi.org/10.1520/D2216-19

49. ASTM D4452-14 (2014) Standard Practice for X-Ray Radiography of Soil Samples, ASTM International, West Conshohocken, PA, 2014. www.astm.org. https://doi.org/10.1520/D4452-14

50. ASTM D698-12 (2012) Standard Test Methods for Laboratory Compaction Characteristics of Soil Using Standard Effort (12 $400 \mathrm{ft}-\mathrm{lbf} / \mathrm{ft} 3(600 \mathrm{kN}-\mathrm{m} / \mathrm{m} 3))$, ASTM International, West Conshohocken, PA, 2012. www.astm.org. https://doi.org/10.1520/ D0698-12

51. ASTM D3080-04 (2004) Standard Test Method for Direct Shear Test of Soils Under Consolidated Drained Conditions, ASTM International, West Conshohocken, PA, 2004. www.astm.org. https://doi.org/10.1520/D3080-04

52. Nasehi SA, Uromeihy A, Nikudel MR, Morsali A (2016) Use of nanoscale zero-valent iron and nanoscale hydrated lime to improve geotechnical properties of gas oil contaminated clay: a comparative study. Environ Earth Sci. https://doi.org/10.1007/ s12665-016-5443-6

53. Zheng X, Zhang J, Zheng T, Liang C, Wang H (2014) A developed technique for measuring water content in oil-contaminated porous media. Environ Earth Sci 71:1349-1356. https://doi.org/ 10.1007/s12665-013-2541-6

54. Fang H-Y, Chaney RC (2016) Introduction to environmental geotechnology. CRC Press, Boca Raton

55. Das BM (2002) Principles of geotechnical engineering, brooks/ cole, wadsworth group. Thompson Learning. Inc., Pacific Grove

56. Das BM (2016) Principles of Foundation Engineering. Global Engineering: Timothy L. Anderson Senior, Cengage
Learning, Dey 12, 1399 AP - Technology \& Engineering - 880 page

57. Wesley LD (2009) Fundamentals of soil mechanics for sedimentary and residual soils. Wiley, Hoboken

58. Mitchell JK, Soga K (1993) Fundamentals of Soil Behavior. Wiley, New York

59. Ur-Rehman H, Abduljauwad SN, Akram T (2007) Geotechnical behavior of oil-contaminated fine-grained soils. Electron J Geotech Eng 12A:2007

60. Shah SJ, Shroff AV, Patel JV, Tiwari KC, Ramakrishnan D (2003) Stabilization of fuel oil contaminated soil-a case study. Geotech Geol Eng. https://doi.org/10.1023/B:GEGE.0000006052. $61830.1 a$

61. Al-Sanad H, Al-Bader B (1990) Laboratory study on leaching of calcareous soil from Kuwait. J Geotech Eng 116:1797-1809

62. Pandey A, Bind YK (2014) Effects of oil contamination on geotechnical properties of alluvial soil Naini Allahabad. Int J Innov Technol Explor Eng 3:2278-3075. https://doi.org/10.1016/j. enggeo.2006.10.009

63. Solly G, Aswathy E, Berlin S, Krishnaprabha N, Maria G (2014) Study on geotechnical properties of diesel oil contaminated soil. Int J Civ Struct Eng Res 2:113-117

64. Lambe TW, Whitman RV (1991) Soil mechanics. Wiley, Hoboken

65. Lambe TW (1958) The structure of compacted clay. J Soil Mech Found Div Proc Am Soc Civil Engrs 84

66. Sridharan A, Venkatappa Rao G (1979) Shear strength behaviour of saturated clays and the role of the effective stress concept. Geotechnique 29(2):177-193. https://doi.org/10.1680/geot. 1979.29.2.177

67. Zhao D (1996) Experimental study of stress-strain and shear strength behavior of contaminated cohesive soils. Ph.D. thesis, Whiting School of Engineering, The Johns Hopkins University, Baltimore. MD, USA

68. Liu ZB, Liu SY, Cai Y (2015) Engineering property test of kaolin clay contaminated by diesel oil. J Cent South Univ 22(12):48374843. https://doi.org/10.1007/s11771-015-3035-3

69. Eissa A, El-Sawwaf M, Shahin M, Nasr A (2017) Effect of kerosine of contamination on geotechnical properties of clayey soils. In Int Conf Adv Struct Geotech Eng (ICASGE'17), 27-30 March 2017, Hurghada, Egypt, pp 44-50

70. Rodríguez Cuervo LS (2018) Index properties, mineralogy composition and strength of clay soil with the presence of diesel. SN Appl Sci. https://doi.org/10.1007/s42452-018-0092-x

71. Olgun M, Yildiz M (2010) Effect of organic fluids on the geotechnical behavior of a highly plastic clayey soil. Appl Clay Sci 48:615-621. https://doi.org/10.1016/j.clay.2010.03.015

72. Ercoli L, Zimbardo M, Nocilla N, Nocilla A, Ponzoni E (2015) Evaluation of cliff recession in the Valle dei Templi in Agrigento (Sicily). Eng Geol 192:129-138. https://doi.org/10.1016/j.enggeo. 2015.04.008

73. Al-Sanad HA, Ismael NF (1997) Aging effects on oil-contaminated Kuwaiti sand. J Geotech Geoenviron Eng 123:290-293

Publisher's Note Springer Nature remains neutral with regard to jurisdictional claims in published maps and institutional affiliations. 